Prepared in cooperation with the Bureau of Reclamation

\title{
Deep Aquifer Recharge in the Columbia River Basalt Group, Upper Umatilla River Basin, Northeastern Oregon
}

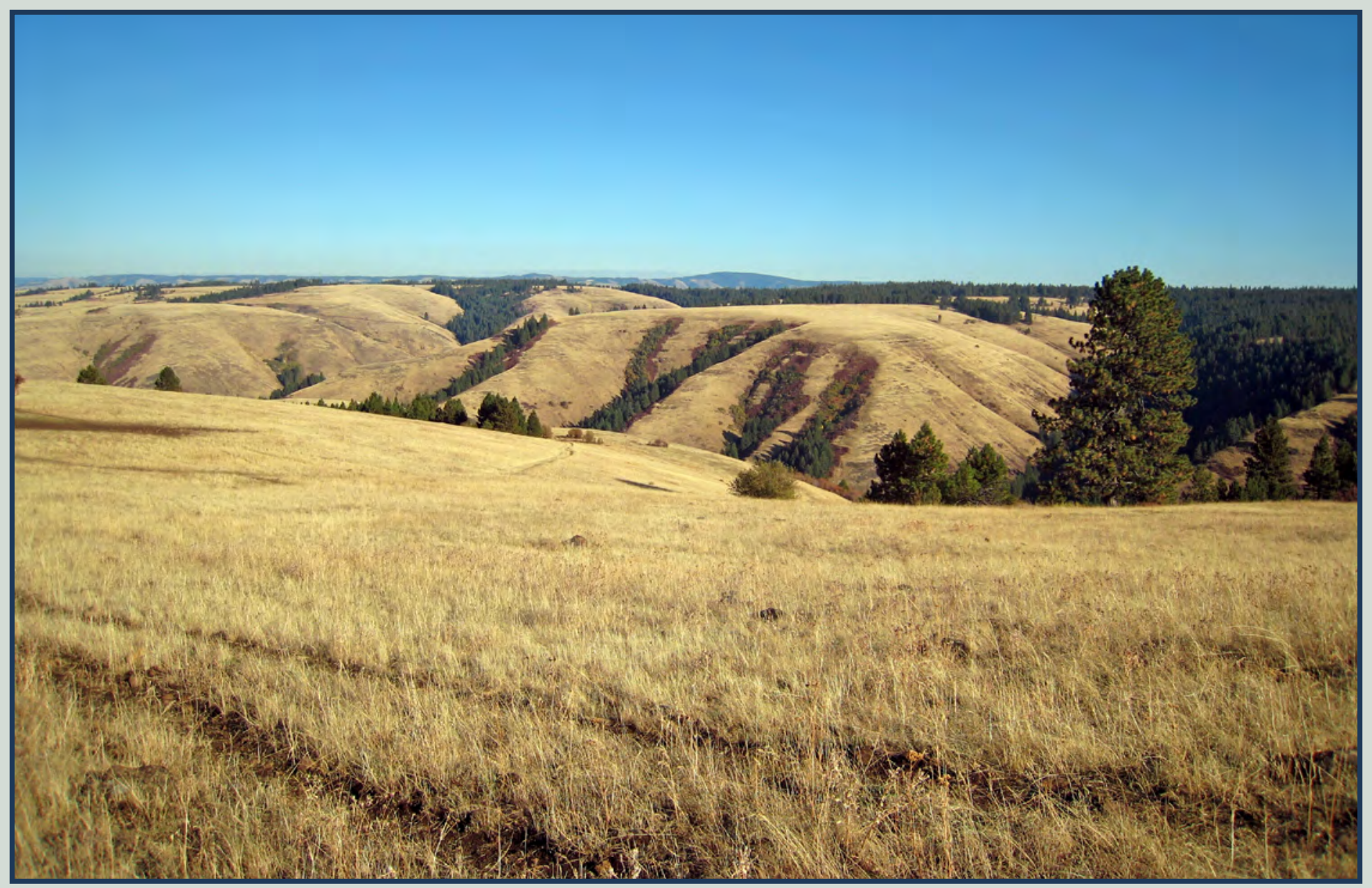

Scientific Investigations Report 2018-5110 
Cover: Photograph showing Upper Umatilla River Basin, Oregon. Photograph by Marshall Gannett, U.S. Geological Survey, summer 2011. 


\section{Deep Aquifer Recharge in the Columbia River Basalt Group, Upper Umatilla River Basin, Northeastern Oregon}

By Esther M. Pischel, Henry M. Johnson, and Stephen B. Gingerich

Prepared in cooperation with the Bureau of Reclamation

Scientific Investigations Report 2018-5110 


\section{U.S. Department of the Interior \\ RYAN K. ZINKE, Secretary}

\section{U.S. Geological Survey James F. Reilly II, Director}

\section{U.S. Geological Survey, Reston, Virginia: 2018}

For more information on the USGS - the Federal source for science about the Earth, its natural and living resources, natural hazards, and the environment-visit https://www.usgs.gov or call 1-888-ASK-USGS.

For an overview of USGS information products, including maps, imagery, and publications, visit https://store.usgs.gov.

Any use of trade, firm, or product names is for descriptive purposes only and does not imply endorsement by the U.S. Government.

Although this information product, for the most part, is in the public domain, it also may contain copyrighted materials as noted in the text. Permission to reproduce copyrighted items must be secured from the copyright owner.

Suggested citation:

Pischel, E.M., Johnson, H.M., and Gingerich, S.B., 2018, Deep aquifer recharge in the Columbia River Basalt Group, upper Umatilla River Basin, northeastern Oregon: U.S. Geological Survey Scientific Investigations Report 2018-5110, 23 p., https://doi.org/10.3133/sir20185110.

ISSN 2328-0328 (online) 


\section{Contents}

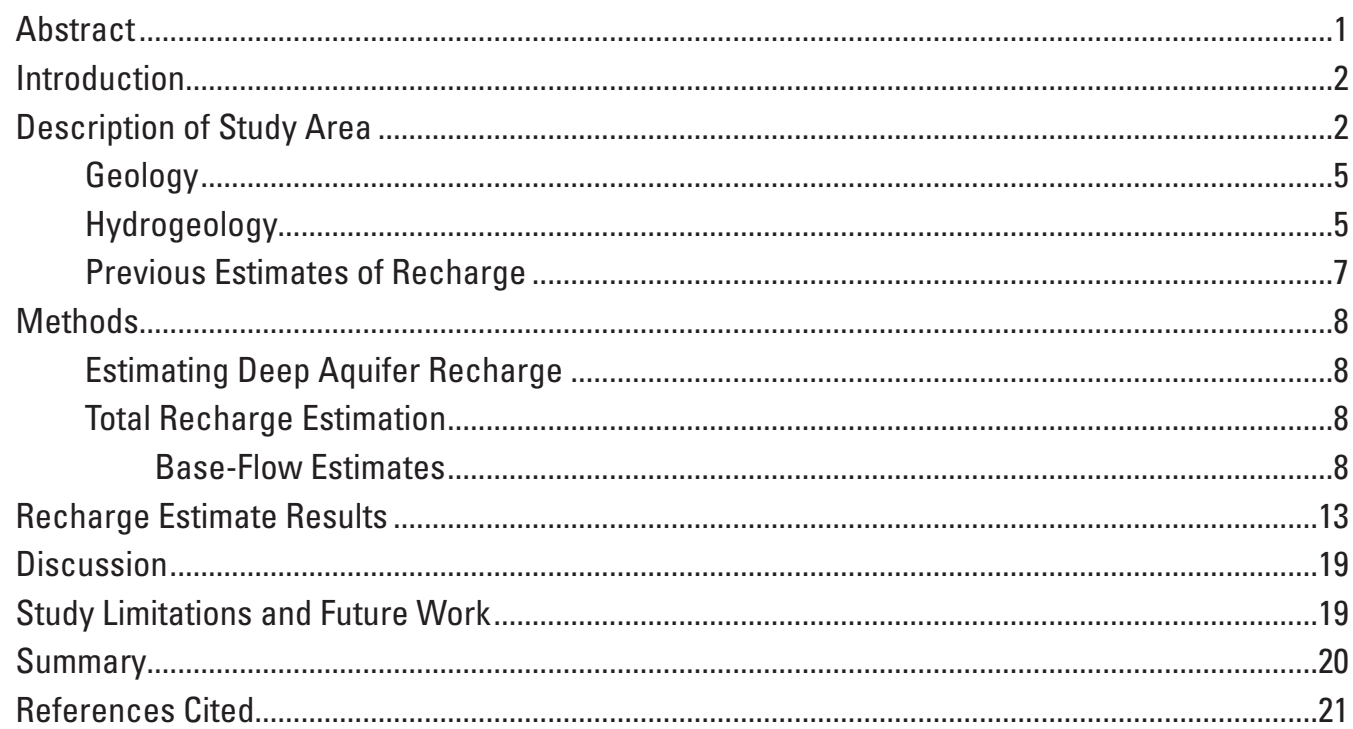

\section{Figures}

1. Map showing location of the study area, topography, and major geographic and cultural features, upper Umatilla River Basin, northeastern Oregon ..................................3

2. Map showing surficial distribution of generalized geologic units in the upper Umatilla River Basin, northeastern Oregon.

3. Diagram showing features within a typical Columbia River Basalt Group flow ................6

4. Conceptual model showing groundwater flow, upper Umatilla River Basin, northeastern Oregon

5. Map showing subbasins and regions in which total recharge, base flow, and deep aquifer recharge were estimated, upper Umatilla River Basin, northeastern Oregon.

6. Map showing mean annual total recharge from precipitation, upper Umatilla River Basin, northeastern Oregon, 1981-2010.

7. Map showing mean annual total recharge from application of irrigation water, upper Umatilla River Basin, northeastern Oregon, 1985-2007

8. Maps showing mean annual total recharge and maximum deep aquifer recharge for selected regions, upper Umatilla River Basin, northeastern Oregon, 1981-2010......15

\section{Tables}

1. Selected recharge budget components, upper Umatilla River Basin, northeastern Oregon 


\section{Conversion Factors}

U.S. customary units to International System of Units

\begin{tabular}{|c|c|c|}
\hline Multiply & By & To obtain \\
\hline \multicolumn{3}{|c|}{ Length } \\
\hline inch (in.) & 2.54 & centimeter $(\mathrm{cm})$ \\
\hline inch (in.) & 25.4 & millimeter $(\mathrm{mm})$ \\
\hline foot $(\mathrm{ft})$ & 0.3048 & meter $(\mathrm{m})$ \\
\hline mile (mi) & 1.609 & kilometer (km) \\
\hline mile, nautical (nmi) & 1.852 & kilometer (km) \\
\hline \multicolumn{3}{|c|}{ Area } \\
\hline acre & 4,047 & square meter $\left(\mathrm{m}^{2}\right)$ \\
\hline acre & 0.4047 & hectare (ha) \\
\hline acre & 0.4047 & square hectometer $\left(\mathrm{hm}^{2}\right)$ \\
\hline acre & 0.004047 & square kilometer $\left(\mathrm{km}^{2}\right)$ \\
\hline square mile $\left(\mathrm{mi}^{2}\right)$ & 259.0 & hectare (ha) \\
\hline square mile $\left(\mathrm{mi}^{2}\right)$ & 2.590 & square kilometer $\left(\mathrm{km}^{2}\right)$ \\
\hline \multicolumn{3}{|c|}{ Volume } \\
\hline acre-foot (acre-ft) & 1,233 & cubic meter $\left(\mathrm{m}^{3}\right)$ \\
\hline acre-foot (acre-ft) & 0.001233 & cubic hectometer $\left(\mathrm{hm}^{3}\right)$ \\
\hline \multicolumn{3}{|c|}{ Flow rate } \\
\hline acre-foot per year (acre-ft/yr) & 1,233 & cubic meter per year $\left(\mathrm{m}^{3} / \mathrm{yr}\right)$ \\
\hline acre-foot per year (acre-ft/yr) & 0.001233 & cubic hectometer per year $\left(\mathrm{hm}^{3} / \mathrm{yr}\right)$ \\
\hline inch per year (in/yr) & 25.4 & millimeter per year $(\mathrm{mm} / \mathrm{yr})$ \\
\hline
\end{tabular}

\section{Datums}

Vertical coordinate information is referenced to the North American Vertical Datum of 1988 (NAVD 88).

Horizontal coordinate information is referenced to the North American Datum of 1983 (NAD 83).

Elevation, as used in this report, refers to distance above the vertical datum.

\section{Abbreviations}

$\begin{array}{ll}\text { BFI } & \text { Base Flow Index } \\ \text { CRBG } & \text { Columbia River Basalt Group } \\ \text { DPM } & \text { deep percolation model } \\ \text { PRMS } & \text { Precipitation-Runoff Modeling System } \\ \text { SOWAT } & \text { SOil WATer balance model }\end{array}$




\title{
Deep Aquifer Recharge in the Columbia River Basalt Group, Upper Umatilla River Basin, Northeastern Oregon
}

\author{
By Esther M. Pischel, Henry M. Johnson, and Stephen B. Gingerich
}

\section{Abstract}

Groundwater is an important component of the water resources of the upper Umatilla River Basin of northeastern Oregon. As such, understanding the capacity of the resource is vital. Past studies have estimated recharge in the study area One recent study of the upper Umatilla River Basin indicated that about 80 percent of recharge entering the groundwater system is discharged to streams in the study area through shallow groundwater-flow paths, leaving about 20 percent of recharge to infiltrate deeper parts of the aquifer system. The purpose of this work is to quantify the spatial distribution and variability of deep aquifer recharge in the study area and to understand the reasons for a relatively low percentage of total recharge reaching the deeper parts of the groundwater-flow system.

The study area is divided into two distinct physiographic regions - the highly dissected Blue Mountains and the lowland plains. Underlying both regions of the study area are basalts of the Columbia River Basalt Group (CRBG), which is the principal aquifer in the study area. Deep incision by streams in the Blue Mountains disrupts the lateral continuity of the $\mathrm{CRBG}$ aquifer units, and infiltrating water is more readily diverted laterally and discharged to streams and springs. In the lowland plains, incision is less pronounced. The shallow CRBG units might be disrupted, but deeper aquifer units retain their lateral continuity and enable groundwater to infiltrate deeper and flow laterally farther downgradient before discharging.

Recharge to the deep basalt aquifers is estimated as the difference between total recharge and base flow. Total recharge is the portion of precipitation and applied irrigation water that infiltrates past the root zone to become groundwater recharge. Of this total recharge, a proportion discharges to springs and streams in the study area, and the remaining water infiltrates below the base level of streams and recharges the deep basalt aquifers and contributes to the regional groundwater flow system. The portion of total recharge that recharges the regional flow system is referred to as deep aquifer recharge.
Total recharge is the portion of precipitation and applied irrigation water that infiltrates past the root zone to become groundwater recharge. It is the sum of recharge from precipitation and recharge from infiltration of irrigation water. Recharge from precipitation was calculated using a regression method developed for the Columbia Plateau. Recharge from infiltrating irrigation water was obtained from a water balance model developed for the Columbia Plateau.

Base flow, the component of streamflow that represents groundwater discharge as opposed to runoff from the land surface, was estimated using the Base Flow Index Modified (BFI-Modified) method, an empirical hydrograph separation technique. Base flow was estimated in eight subbasins with streamgages within the study area. Five of the eight subbasins in which base flow was estimated had permitted water rights for irrigation that specified surface water as the primary source of water. Maximum surface-water withdrawal for irrigation was estimated for all subbasins in which water rights for irrigation occur.

The base-flow estimate from BFI-Modified is assumed to be the minimum amount of base flow. The sum of the BFIModified base-flow estimate and the maximum permitted surface-water withdrawal estimate for each subbasin is assumed to be the maximum amount of base flow at the streamgage. These minimum and maximum estimates of base flow were used to calculate minimum and maximum values of deep aquifer recharge in each subbasin analyzed within the study area. Subbasin estimates were scaled up to the Blue Mountains and lowland plains regions, and to the entire study area.

Mean annual total recharge for 1981-2010 in the subbasins, analyzed as part of this work, ranged from 6 inches (in.) in the Patawa and Wildhorse Creek subbasins in the lowland plains to as much as 20 in. in the Umatilla River above Meacham Creek subbasin. Mean annual total recharge totaled 4 in. in the lowland plains region and 14 in. in the Blue Mountains. Mean annual total recharge for the entire study area was 11 in. 
Mean annual base flow ranged from 1 in. in the Patawa and Wildhorse Creek subbasins in the lowland plains to as much as 14 in. in the Umatilla River above Meacham Creek subbasin in the Blue Mountains.

Mean annual deep aquifer recharge ranged from 4 in. in the Patawa and Wildhorse Creek subbasins in the lowland plains to as much as $8 \mathrm{in}$. in the Isqu'ulktpe Creek subbasin in the Blue Mountains. Deep aquifer recharge was 3-4 in. in the lowland plains region and 6 in. in the Blue Mountains.

Over the entire study area, mean annual deep aquifer recharge was 5 in.

Most groundwater recharge (both total and deep aquifer) in the study area occurred in the Blue Mountains, which highlights the importance of the Blue Mountains as the principal source of groundwater for the study area and for aquifers farther downgradient. Total recharge in the Blue Mountains region represents 86 percent of the mean annual total recharge in the study area in an area that encompasses 65 percent of the study area. However, only 43-44 percent of the mean annual total recharge remains in the system to recharge the deeper, regional aquifer system because the rest is discharged as base flow within the Blue Mountains region. Within the lowland plains region of the study area, an estimated 67-84 percent of the mean annual total recharge remains in the system to recharge the deep, regional aquifer system. Although total recharge in the study area represents only 14 percent of the total recharge across the study area, it contributes 20-24 percent of the water to the deep aquifer.

The difference in the percentage of deep groundwater recharge in the Blue Mountains and the lowland plains is attributed to differences in the degree of stream incision. Stream channels are more incised in the Blue Mountains region than they are in the lowland plains. The dissection of the landscape in the Blue Mountains disrupts the lateral continuity of the CRBG aquifer units and allows groundwater to discharge to springs and streams rather than infiltrate more deeply. In the lowland plains region, incision is much less pronounced and deeper CRBG units likely retain their lateral continuity, enabling groundwater to infiltrate more deeply than in the Blue Mountains.

\section{Introduction}

Groundwater is an important component of the water resources of the semi-arid upper Umatilla River Basin of northeastern Oregon (fig. 1). As such, understanding the capacity of the groundwater resource is vital.

Past studies have quantified groundwater recharge in the upper Umatilla River Basin but lacked an evaluation of the spatial distribution of recharge to the underlying aquifer. This study provides a refined recharge estimate for the upper
Umatilla River Basin that accounts for spatial variability in the landscape and quantifies the proportion of recharge that infiltrates deeply to the regional groundwater system.

The purpose of this work is to better quantify the spatial distribution and variability of deep aquifer recharge in the study area, and to understand the reasons for a relatively low percentage of total recharge reaching the deeper parts of the groundwater-flow system.

\section{Description of Study Area}

The 914-mi ${ }^{2}$ upper Umatilla River Basin (hereinafter, "study area") encompasses the drainage of the Umatilla River from its headwaters in the Blue Mountains downstream to just west of the confluence of the Umatilla River with Wildhorse and McKay Creeks (fig. 1). Major tributaries to the Umatilla River in the study area include Meacham Creek, McKay Creek, and Wildhorse Creek. The Umatilla Indian Reservation, home of the Confederated Tribes of the Umatilla Indian Reservation, is almost completely contained within the study area. The largest city in the study area is Pendleton; other major communities include Mission, Athena, and Meacham.

The study area is divided into two distinct physiographic areas - the Blue Mountains to the east and gently undulating, lowland plains to the west. The Blue Mountains and lowland regions of the study area are referred to hereinafter as the Blue Mountains and lowland plains, respectively (fig. 1). The Blue Mountains are highly dissected by streams and range in elevation from 1,600 to 5,800 ft; they are sparsely populated and largely forested. The lowland plains range in elevation from 950 to $2,500 \mathrm{ft}$, and have much more subdued topography compared to the Blue Mountains. The foothills and gently rolling plains in this region support the major communities and nearly all the agricultural development in the study area.

Mean annual precipitation is greatest in the upper elevations of the Blue Mountains and generally decreases to the west with decreasing elevation. Mean annual precipitation averaged $28 \mathrm{in}$. across the study area during 1981-2010, and ranged from 55 to 13 in. (PRISM Climate Group, 2016). Mean annual precipitation in the Blue Mountains region averaged 34 in. during 1981-2010 (PRISM Climate Group, 2016), much of which fell as snow. The long-term mean annual (1948-2016) snowfall at the Emigrant Springs SNOTEL site in the Blue Mountains near Meacham is 147 in., of which 85 percent fell between November and March; the snowpack depth peaks in February and generally has melted by May (Western Regional Climate Center, 2018). In contrast, precipitation averaged $18 \mathrm{in}$. across the lowland plains in the western part of the study area. 


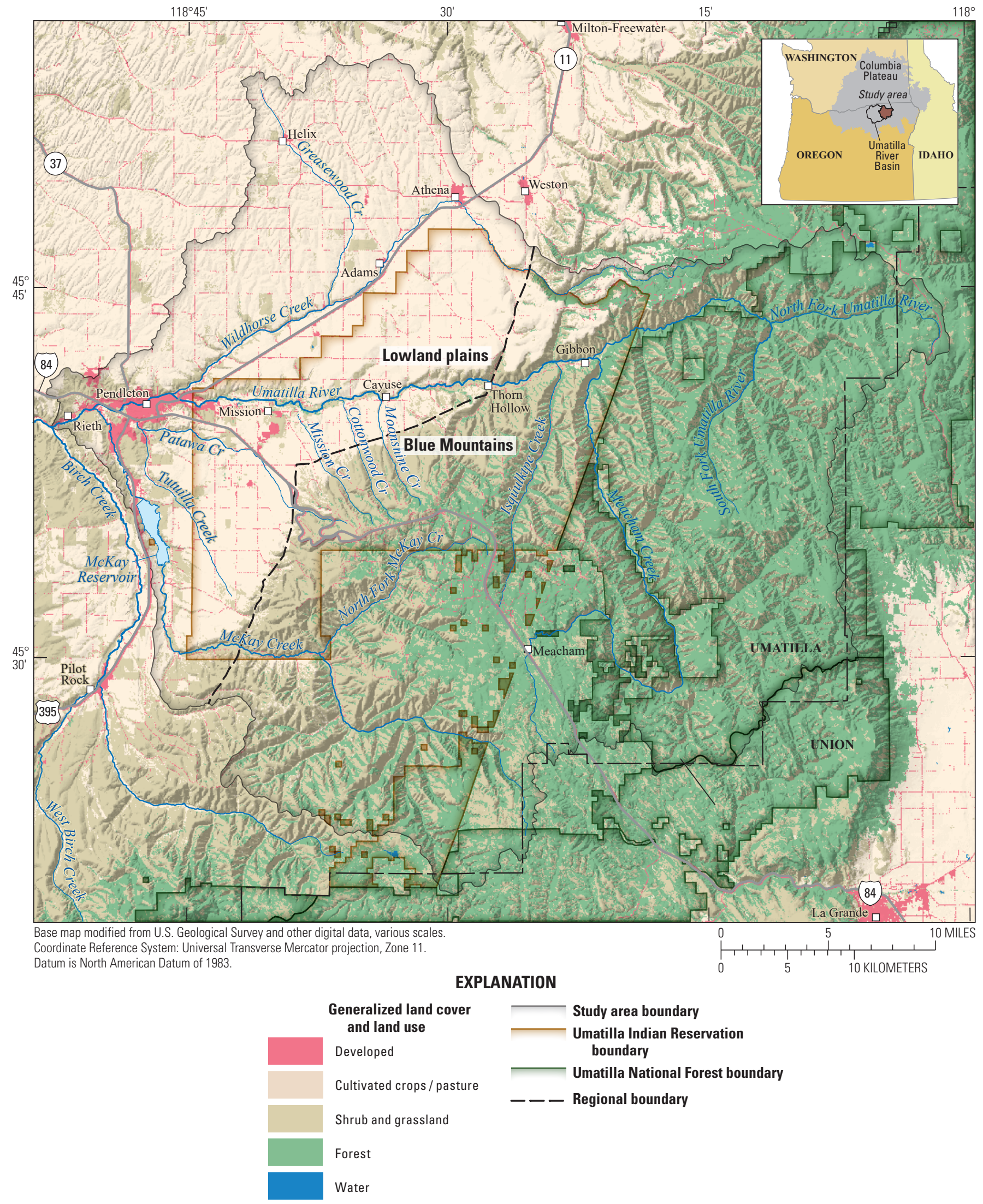

Figure 1. Location of the study area, topography, and major geographic and cultural features, upper Umatilla River Basin, northeastern Oregon. Modified from Herrera and others (2017). 


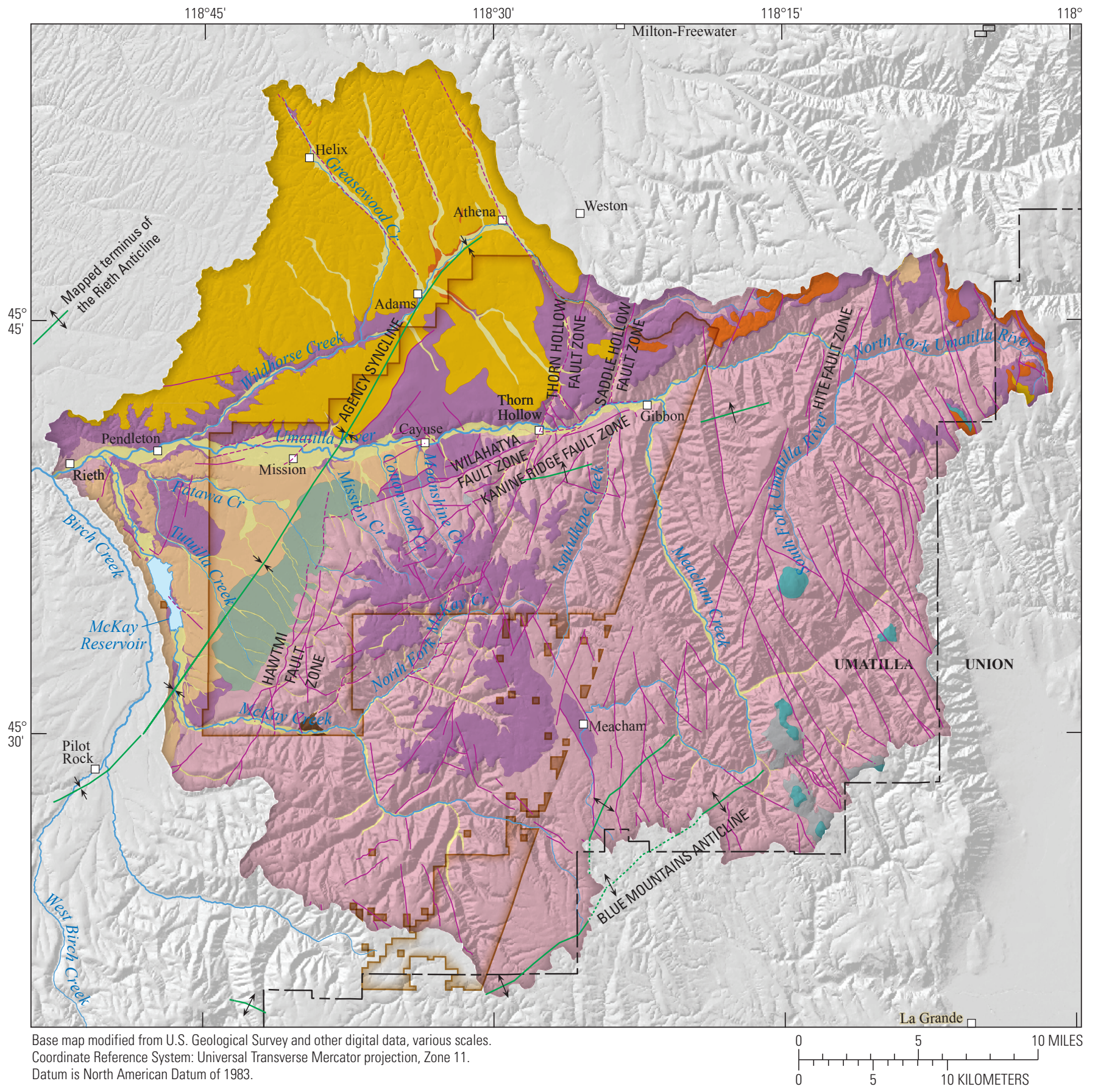

EXPLANATION
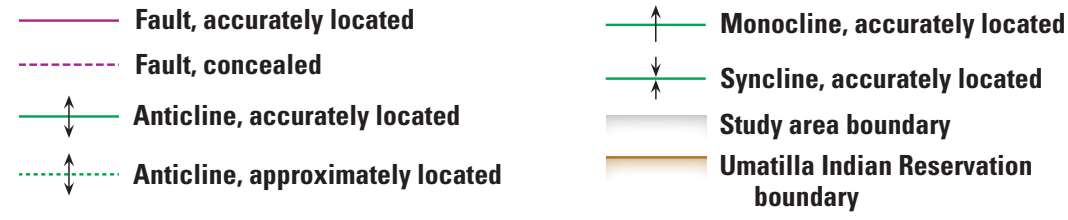

Figure 2. Surficial distribution of generalized geologic units in the upper Umatilla River Basin, northeastern Oregon. Modified from Herrera and others (2017). 
EXPLANATION

\begin{tabular}{|c|c|c|c|c|}
\hline $\begin{array}{c}\text { Generalized } \\
\text { geologic units } \\
\text { —shown on } \\
\text { map }\end{array}$ & $\begin{array}{l}\text { Generalized hydrogeologic } \\
\text { units }\end{array}$ & Period & Epoch & $\begin{array}{l}\text { Upper Umatilla River Basin } \\
\text { simplified geologic map unit }\end{array}$ \\
\hline Qal & \multirow{5}{*}{ Sediment } & \multirow{3}{*}{ Quaternary } & \multirow{3}{*}{$\begin{array}{l}\text { Pleistocene } \\
\text { to Holocene }\end{array}$} & Alluvium and terrace deposits \\
\hline Qf & & & & Alluvial fan deposits \\
\hline Qls & & & & Landslide deposits \\
\hline QTs & & $\begin{array}{l}\text { Quaternary- } \\
\text { Tertiary }\end{array}$ & $\begin{array}{l}\text { Late Miocene } \\
\text { to Pleistocene }\end{array}$ & Loess, silt, and sand deposits \\
\hline Tms & & \multirow{5}{*}{ Tertiary } & \multirow{2}{*}{$\begin{array}{l}\text { Middle Miocene } \\
\text { to Pliocene }\end{array}$} & Sedimentary rocks, McKay Formation \\
\hline Tpv & Grande Ronde basalt & & & Volcanic rocks, Powder River Volcanic Field \\
\hline Tsu & Saddle Mountains basalt & & Middle to Late Miocene & Basalt, Saddle Mountains Basalt Formation \\
\hline Twu & Wanapum basalt & & Middle Miocene & Basalt, Wanapum Basalt Formation \\
\hline Tgu & Grande Ronde basalt & & $\begin{array}{l}\text { Early to Middle } \\
\text { Miocene }\end{array}$ & Basalt, Grande Ronde Formation \\
\hline Tjda & $\begin{array}{l}\text { Igneous and metamorphic } \\
\text { rocks (basement) }\end{array}$ & $\begin{array}{l}\text { Tertiary and } \\
\text { Pre-Tertiary }\end{array}$ & Oligocene and older & $\begin{array}{l}\text { Undifferentiated sedimentary, volcanic, } \\
\text { igneous, and metamorphic rocks }\end{array}$ \\
\hline
\end{tabular}

Figure 2.-Continued

\section{Geology}

Basalts of the Columbia River Basalt Group (CRBG) underlie the study area. The CRBG basalts were emplaced from about 17 to 6 million years ago and consist of numerous individual flows of highly fluid basalt that inundated the entirety of the study area. Coeval with emplacement of the CRBG, the region experienced extensive folding and faulting (Ferns and others, 2006). The Hawtmi, Wilahatya, and Thorn Hollow Fault Zones separate the uplands of the Blue Mountains from the lowland plains (fig. 2). Folding and faulting uplifted the Blue Mountains relative to the lowland plains to the west, and have resulted in deep incision by streams on the uplifted block. Sediment eroded from the Blue Mountains forms several deposits in the lowland plains, including the low-permeability conglomerate of the McKay Formation, loess and fine-grained sandstone, alluvial fan deposits, and recent stream alluvium (Hogenson, 1964; Herrera and others, 2017). For a detailed description of study area geology, see Herrera and others (2017).

\section{Hydrogeology}

Groundwater occurs in sedimentary deposits and the underlying basalt of the CRBG. For detail on these units, see Herrera and others (2017).
The sedimentary aquifer is composed of deposits derived from the erosion of the uplifted Blue Mountains. Total thickness of the sedimentary aquifer in the study area is as much as $320 \mathrm{ft}$. In the lowland plains, the aquifer is laterally extensive; in the uplands of the Blue Mountains, it is primarily present in stream valleys (Herrera and others, 2017, fig. 6A). Groundwater withdrawals from the sedimentary aquifer generally are limited to livestock and domestic uses (Hogenson, 1964).

The CRBG is the principal aquifer in the study area, and is composed of numerous basaltic lava flows stacked one upon the other; individual flows within the CRBG aquifer range in thickness from 5 to more than $100 \mathrm{ft}$. Total thickness of the CRBG in the study area may be as much as 6,800 ft (Herrera and others, 2017). In general, the flows are laterally extensive except where cut by faulting, incised by streams, or pinched out by paleotopography. The vesicular and brecciated tops and bottoms of individual flows are the principal aquifers and water-bearing zones; the flow interiors typically are dense and have much lower permeability than the flow tops and bottoms (fig. 3). Kahle and others (2011) summarized published values of horizontal and vertical hydraulic conductivity values for the CRBG, and although there is a considerable range, most estimates yield a horizontal to vertical anisotropy of 1,000-10,000. Numerous reports have documented substantial differences in hydraulic head between vertically separated 
water-bearing zones within the CRBG, further attesting to the low permeability of the flow interiors (Hansen and others, 1994; Kahle and others, 2011; Burns and others, 2012; Herrera and others, 2017).

In the Blue Mountains, streams are deeply incised through CRBG strata, whereas on the lowland plains, stream incision is less pronounced. Where the CRBG strata are deeply incised, the lateral continuity of the CRBG aquifer units is disrupted and infiltrating groundwater is more readily diverted laterally and discharged to streams and springs (fig. 4). Where incision is less pronounced, the shallow CRBG aquifer units might be disrupted, but deeper units retain their lateral continuity and enable groundwater to infiltrate deeper and flow laterally farther downgradient before discharging.

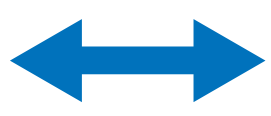

Upper colonnade

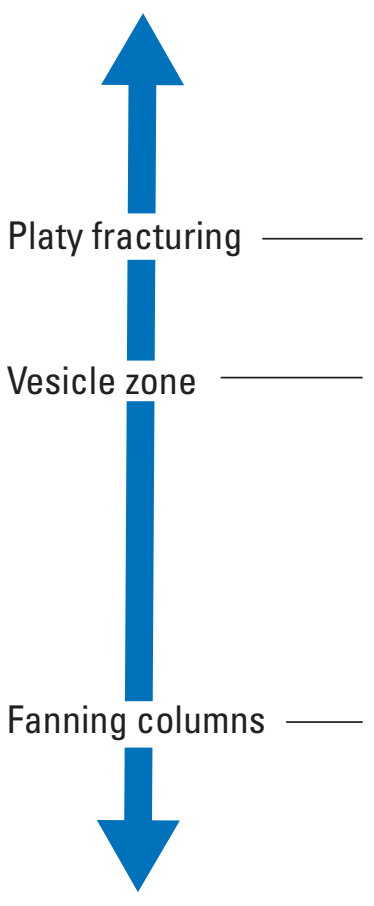

Vesicle sheets and cylinders

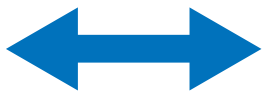

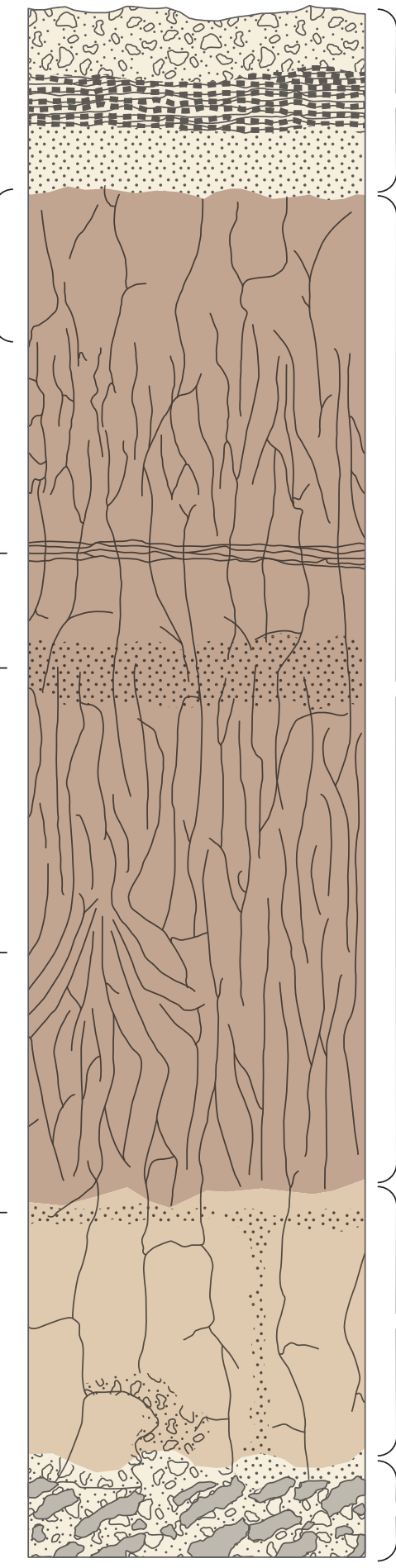

\section{Flow top zone}

Vesicular to rubbly and/or brecciated basalt

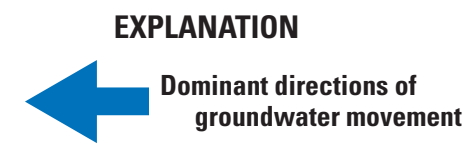

\section{Flow interior}

\section{Colonnade}

Entablature

Flow bottom zone

Pillow-palagonite complex, vesicular base, rubble or breccia

Figure 3. Features within a typical Columbia River Basalt Group flow. From Kahle and others (2011). 


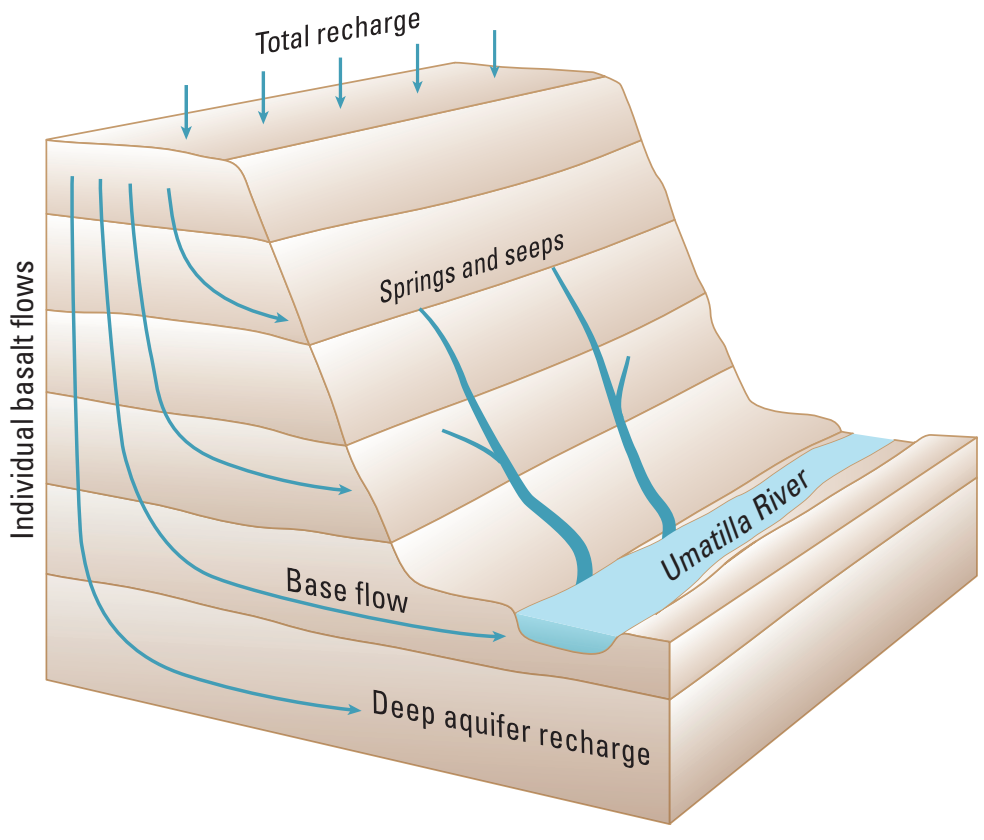

Figure 4. Conceptual model showing groundwater flow, upper Umatilla River Basin, northeastern Oregon.

\section{Previous Estimates of Recharge}

Past studies have made estimates of recharge within or adjacent to the study area. Davies-Smith and others (1988) developed a groundwater model of a part of the Columbia Plateau that includes much of the lowland plains part of this study area, but omits much of the upland Blue Mountains. Davies-Smith and others (1988) estimated annual recharge to range from 0.2 in. near Pendleton to 3 in. in the foothills of the Blue Mountains during 1956-77 using a soil and energy balance model of the Columbia Plateau (deep percolation model [DPM]; Bauer and Vaccaro, 1987). Recharge estimates for their model domain include recharge from precipitation and application of irrigation water from streams.

Bauer and Vaccaro (1990) estimated recharge for the Columbia Plateau of eastern Washington, northeastern Oregon (including the Umatilla River Basin), and parts of northwestern Idaho using the DPM (Bauer and Vaccaro, 1987). For the study area described in this report, estimated annual recharge ranged from about $0.1 \mathrm{in}$. on the lowland plains to more than 10 in. in the Blue Mountains during 1956-77 (Bauer and Vaccaro, 1990, pl. 2).

Using the DPM (Bauer and Vaccaro, 1987), Gonthier and Bolke (1993) estimated recharge over the Umatilla Reservation area to be "about 0.6 inches in the lowland areas along the west and northwest reservation boundary to more than 3 in. the uplands east of Thorn Hollow" (Gonthier and Bolke, 1993, p. 25). The period for which the recharge estimate applied was not provided.

Ely and others (2014) developed a groundwatersimulation model of the Columbia Plateau that included the study area. Recharge was estimated for unirrigated areas using a regression method developed from the DPM (Bauer and Vaccaro, 1987, 1990) and using the SOil WATer balance (SOWAT) model (Kahle and others, 2011) in areas of irrigated agriculture. In the study area, annual recharge for 2000-07 land-use conditions was estimated to range from about 2 in. near Pendleton to a maximum of 40 in. in the Blue Mountains (Ely and others, 2014, fig. 14B).

Herrera and others (2017) developed a groundwater budget for the study area also using the regression method developed from the DPM (Bauer and Vaccaro, 1987, 1990). Estimated mean annual recharge from precipitation in the study area during 1951-2010 was 9.6 in., and ranged from about 2 in. in the lowland near Pendleton to nearly 34 in. in the high elevations of the Blue Mountains.

Yazzie and Chang (2017) developed a PrecipitationRunoff Modeling System (PRMS; Leavesley and others, 1983; Markstrom and others, 2015) model for a part of the study area upstream of a streamgage near Pendleton (Umatilla River at West Reservation Boundary near Pendleton, Oregon [U.S. Geological Survey streamgage 14020850]). The calibrated model estimated a mean annual basin recharge of $16.8 \mathrm{in.}$ during 1970-1999 (Yazzie and Chang, 2017, table 7).

Previous annual recharge estimates for the study area ranged from 0.1 to 2 in. in the lowlands near Pendleton and from 10 to $40 \mathrm{in}$. in the Blue Mountains. Much of this variability is due to differences in precipitation during the various periods used and differences in size of the study area under investigation by each study.

Herrera and others (2017) indicated that about 80 percent of recharge entering the groundwater system is discharged to streams in the study area through shallow groundwater-flow paths, leaving about 20 percent of recharge to infiltrate deeper parts of the aquifer system. This deep recharge supplies water to the basalt aquifers in the lowland part of the study area (and farther downgradient), from which groundwater most often is withdrawn for municipal and irrigation uses. This has important implications for the use and management of water in the deep basalt aquifers of the study area, as well as those downgradient aquifers underlying the lower Umatilla River Basin to the west. 


\section{Methods}

In this report, recharge to the deep basalt aquifers is estimated as the difference between total recharge and base flow. Total recharge is the portion of precipitation and applied irrigation water that infiltrates past the root zone to become groundwater recharge. Of this total recharge, a proportion discharges through shallow and intermediate flow paths to springs and streams in the study area, and the remaining water infiltrates below the base level of streams and recharges the deep basalt aquifers and contributes to the regional groundwater flow system. Groundwater withdrawals from the sediments overlying the basalt aquifer likely are insignificant and are not factored into this relation. The portion of total recharge that recharges the regional groundwater flow system is referred to as deep aquifer recharge (fig. 4).

\section{Estimating Deep Aquifer Recharge}

A simple relation can be defined between total recharge, base flow, and deep aquifer recharge. The portion of total recharge that does not reemerge as base flow is available to become deep aquifer recharge. This is expressed by the equation,

Deep Aquifer Recharge $=$ Total Recharge - Base Flow.

Comparison of total recharge and base flow requires records that are spatially and temporally coincident. To ensure that estimates of total recharge and base flow were spatially coincident, deep aquifer recharge was estimated for subbasins with streamgage records that could be used to estimate base flow (fig. 5). Base-flow estimates from these streamgages were scaled up to provide estimates for the Blue Mountains and lowland plains regions and for the entire study area (fig. 5). To ensure that estimates were temporally coincident, base-flow estimates were normalized to the 1981-2010 recharge period.

\section{Total Recharge Estimation}

Recharge from infiltration of precipitation is estimated using a regression method developed from the DPM (Bauer and Vaccaro, 1987, 1990) relating annual recharge to annual precipitation:

$$
\mathrm{R}_{\mathrm{p}}=\left(\mathrm{P}^{2} \times 0.00865\right)+(\mathrm{P} \times 0.1416)-1.28
$$

where

$$
\begin{aligned}
R_{p} & \text { is recharge from precipitation, in inches, and } \\
P & \text { is precipitation, in inches. }
\end{aligned}
$$

Equation 2 was developed by Bauer and Vaccaro (1990) using the DPM (Bauer and Vaccaro, 1987). The regression equation predicts recharge as a function of mean annual precipitation with a correlation coefficient of 0.92. Equation 2 yields negative values when annual precipitation is less than 6.49 in.; however, annual precipitation is more than $6.49 \mathrm{in}$. throughout the current study area. Using this regression equation, Herrera and others (2017) estimated annual recharge for the study area during 60 water years (1951-2010) using 2.48-mi gridded precipitation values (Herrera and others, 2017). This study extends that work by estimating total recharge for the study area using similar methods but at a finer spatial resolution. For this analysis, the mean annual recharge from precipitation was estimated for 1981-2010 using 30 arcsecond (about 0.5 -mi) gridded precipitation values (PRISM Climate Group, 2016; fig. 6). The 1981-2010 period was chosen because it was a period during which high-resolution precipitation data were available.

Recharge from infiltrating irrigation water $\left(\mathrm{R}_{\mathrm{i}}\right)$ was obtained from the SOil WATer balance (SOWAT) model used by Kahle and others (2011). Total recharge was estimated as the sum of recharge from precipitation $\left(\mathrm{R}_{\mathrm{p}}\right)$ and $\mathrm{R}_{\mathrm{i}}$. A U.S. Geological Survey data release by Pischel (2018) can be used to access the recharge datasets (from irrigation and from precipitation).

\section{Base-Flow Estimates}

Base flow refers to the component of streamflow that represents groundwater discharge, rather than runoff from the land surface. The base-flow component of streamflow can be estimated using empirical hydrograph separation techniques, such as Base Flow Index (BFI) (Wahl and Wahl, 1995), PART (Rutledge, 1998), and HYSEP (Sloto and Crouse, 1996). These methods all use recession-curve analysis to identify parts of a streamflow hydrograph when surface runoff is negligible; during these periods, streamflow is assumed to equal base flow (groundwater discharge.) The method used in this investigation was the Base Flow Index Modified (BFI-Modified) method (Barlow and others, 2015). The BFIModified method was used for this work because it typically generates lower estimates of base flow when compared with other recession-curve methods, particularly in snowmeltdominated systems such as the study area. The larger baseflow estimates generated by PART and HYSEP are not necessarily incorrect, and results from those methods can be interpreted as including more shallow flow-path groundwater. However, because the DPM accounts for shallow subsurface flow (to some extent), a recharge method with a smaller subsurface flow component (such as BFI-Modified) is a better pairing with that model. Additionally, in the development of the regression method of Bauer and Vaccaro (1990), total streamflow (measured at many streamgages) was apportioned into runoff and base flow. Although the exact method of estimating base flow was not specified, the base-flow estimates were described as "low" (Bauer and Vaccaro, 1990, p. 17). 


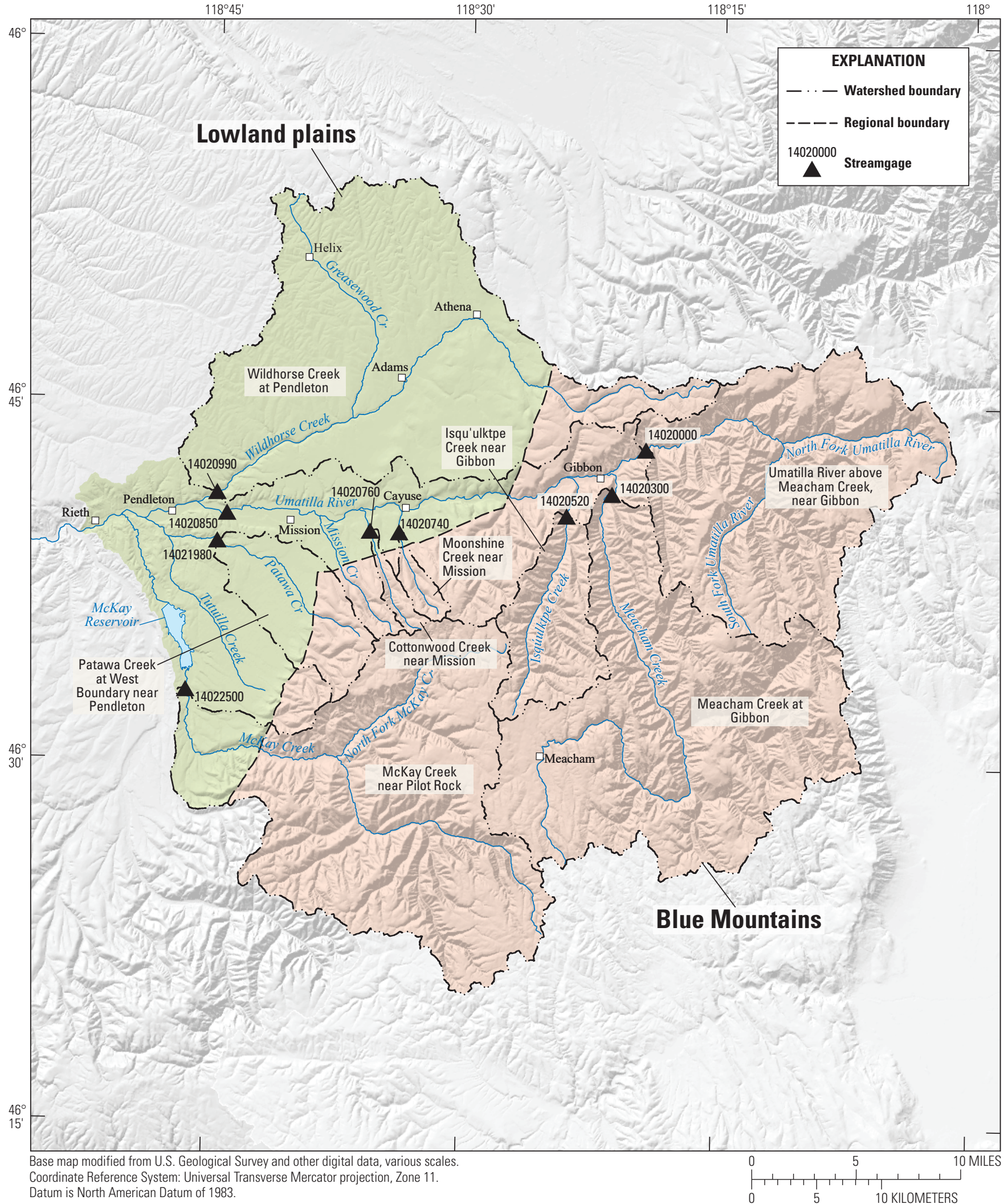

Figure 5. Subbasins and regions in which total recharge, base flow, and deep aquifer recharge were estimated, upper Umatilla River Basin, northeastern Oregon. Subbasins with streamgages are denoted by the name of their streamgage. 


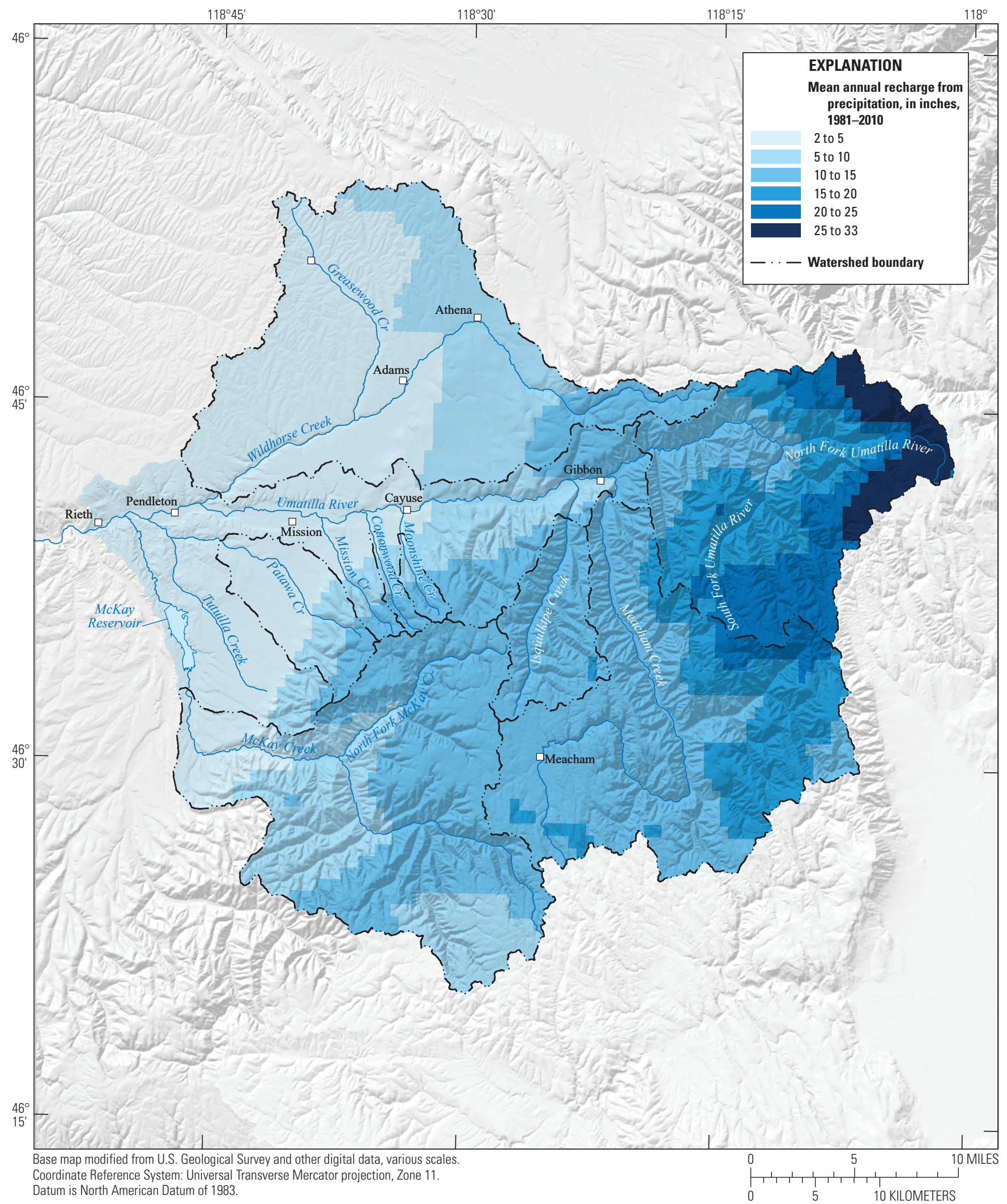

Figure 6. Mean annual total recharge from precipitation, upper Umatilla River Basin, northeastern Oregon, 1981-2010. 
"Low" base-flow estimates are commensurate with a BFIModified base-flow estimate. By using a low estimate for base flow, the estimated deep aquifer recharge is maximized and, therefore, provides an upper bound on the amount of deep water moving through the system. Base flow was estimated in eight subbasins with streamgages within the study area (fig. 5; table 1). The subbasin boundary dataset is accessible in the U.S. Geological Survey data release by Pischel (2018).

The streamgages used in this study did not have coincident periods of record; therefore, the base-flow estimates from each site were normalized to the recharge period (1981-2010) using the base-flow estimate from the reference streamgage (Umatilla River above Meacham Creek near Gibbon, Oregon [U.S. Geological Survey streamgage 14020000]; fig. 5), which had the longest period of record (1934-2015). The period of record for the reference streamgage completely encompasses the recharge period and the period of record of all the other streamgages used in this study. Base flow for each site was normalized to the 1981-2010 base flow at the Umatilla River above Meacham Creek by dividing the base flow by a scaling factor calculated using:

$$
S F_{k}=\frac{B F R_{i-j}}{B F R_{1981-2010}},
$$

where

$$
\begin{aligned}
& S F_{k} \quad \text { is the scaling factor for streamgage } k \text {; } \\
& i \quad \text { is the first year of the period of record for } \\
& \text { streamgage } k \text { (or 1981, if the period of } \\
& \text { record begins before 1981); } \\
& j \quad \text { is the last year of the period of record for } \\
& \text { streamgage } k \text { (or 2010, if the period of } \\
& \text { record extends past 2010); } \\
& B F R_{i-j} \quad \text { is the mean annual base flow of the reference } \\
& \text { streamgage for the years } i \text { through } j \text {; and } \\
& B F R_{1981-2010} \text { is the mean annual base flow of the reference } \\
& \text { streamgage for the years } 1981 \text { through } \\
& 2010 .
\end{aligned}
$$

Base-flow scaling factors for streamgages in this report ranged from about 0.9 to 1 .

Five of the eight subbasins had permitted water rights for irrigation that specified surface water as the primary source of water. These water rights were associated with 4,539 acres, of which 79 percent were in the two subbasins in the lowland plains region, Patawa and Wildhorse Creeks (Jen Woody, Oregon Water Resources Department, written commun., 2018). The permitted water rights indicate the maximum legal amount of water that can be withdrawn from a stream by the holder. The amount of water actually withdrawn by permit holders is not known; water withdrawal is subject to availability and is unmeasured. An annual application rate of 2.5 acre-ft per acre was assumed based on crop types observed in the area by Oregon Water Resources Department staff, and represents a maximum volume of water that could be withdrawn. As such, estimates of surface-water withdrawal should be considered maximum estimates (table 1). The timing of permitted withdrawals also is unknown; however, most of the withdrawals for surface-water irrigation likely occur during summer, when streamflow is at or near baseflow conditions. The base-flow estimate from BFI-Modified is assumed to be the minimum amount of base flow, and the BFI-Modified base-flow estimate plus the maximum permitted surface-water withdrawal for each subbasin is assumed to be the maximum amount of base flow at the streamgage.

A maximum and minimum value of deep aquifer recharge was calculated for each subbasin. Maximum and minimum deep aquifer recharge is dependent on the volume of base flow that exits the groundwater system in each subbasin. The greater the volume of base flow exiting the groundwater system, the less groundwater will be available to percolate deeply to the deeper regional basalt aquifer. Thus, minimum deep aquifer recharge is

$$
\begin{aligned}
& \text { Total recharge - (BFI-modified base flow } \\
& + \text { estimated surface water diversions) }
\end{aligned}
$$

where total recharge is recharge from precipitation and applied irrigation water, and the sum of BFI-modified baseflow and estimated surface-water diversions represents maximum baseflow.

Maximum deep aquifer recharge is Total recharge - BFI-modified base flow,

where total recharge is recharge from precipitation and applied irrigation water, and BFI-modified base flow represents minimum base flow. 


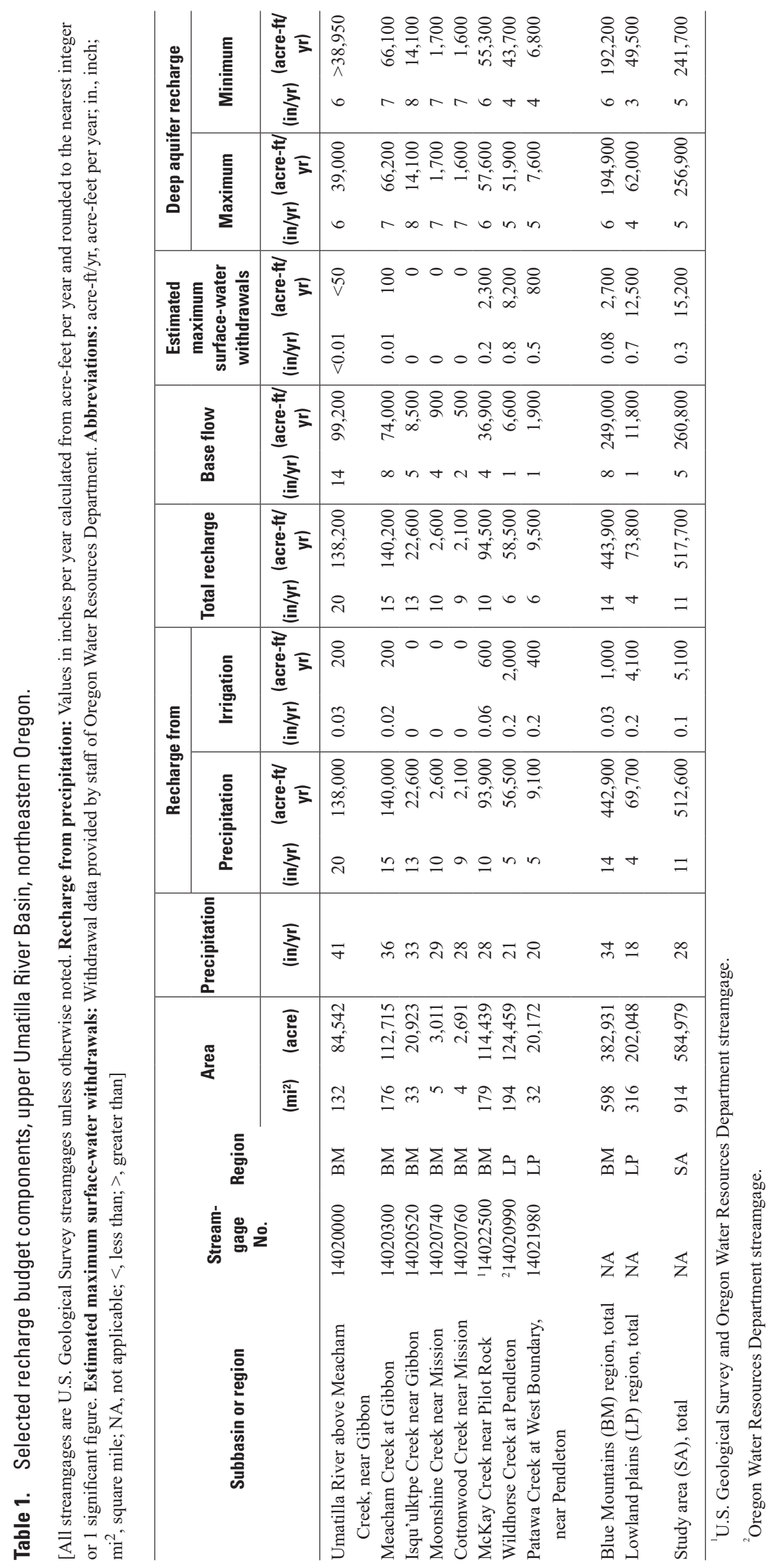


To calculate maximum and minimum values of deep aquifer recharge for the Blue Mountains and lowland plains regions, the same relations defined in the preceding paragraphs were used, but values of base flow and estimated surfacewater diversions were scaled up from subbasin estimates. For each region, the total base flow and surface-water diversions within subbasins of that region were scaled by the ratio of the area of the subbasins with streamgages to the total region area. For example, base flow in the Blue Mountains region was calculated by first summing the base flow that occurs in the subbasins within the Blue Mountains region (Umatilla River above Meacham Creek, Meacham Creek, Isqu'ulktpe Creek, Moonshine Creek, Cottonwood Creek, and McKay Creek). This total base-flow value (220,000 acre-ft/yr) was then scaled by the ratio of the area with streamgages (338,321 acres) to total area in the Blue Mountains region (382,931 acres) - 1.1. Multiplying the total base flow in the Blue Mountains subbasins with streamgages by the ratio of gaged to total region area resulted in the (rounded) value of 249,000 acre-ft/yr for the Blue Mountains region. Scaled values of base flow and surface-water diversions were derived in this way for the Blue Mountains and lowland plains regions, and used in the relations defined here to calculate minimum and maximum deep aquifer recharge in each region.

To calculate deep aquifer recharge for the entire study area, the scaled values of base flow and estimated surfacewater diversions were added to obtain study area-wide values of base flow and surface-water diversions. These values were used in the relations defined here to calculate minimum and maximum deep aquifer recharge for the study area. The study area boundary, which is subdivided into the Blue Mountains and lowland plains regions, is accessible in the U.S. Geological Survey data release by Pischel (2018).

\section{Recharge Estimate Results}

Mean annual total recharge for the study area (584,979 acres) during 1981-2010 was estimated at $11 \mathrm{in.}$ (517,700 acre-ft) (table 1). It ranged from about 2 in. in the drier west side of the study area near Pendleton to as much as about 33 in. in the Blue Mountains (fig. 6). Less than 1 percent of the total recharge was from applied irrigation water (fig. 7). It was larger, but still relatively small, in the two subbasins in the lowland plains region where it contributed 3-4 percent of the total recharge. In the various subbasins, mean annual total recharge ranged from 6 in. in the Patawa Creek and Wildhorse Creek subbasins to as much as 20 in. in the Umatilla River above Meacham Creek subbasin (table 1; fig. 8A). Mean annual total recharge in the Blue Mountains region was estimated at 14 in. (443,900 acre-ft), and 4 in. (73,800 acre-ft) in the lowland plains region (table 1; fig. $8 \mathrm{C}$ ).
A PRMS model developed for a $442-\mathrm{mi}^{2}$ watershed within the current study area estimated a mean annual recharge over the PRMS model domain of 16.8 in. during 1970-1999 (Yazzie and Chang, 2017). This estimate is about 13 percent higher than the estimate for this study when the same area is considered.

Mean annual base flow estimated from the BFI-Modified method in subbasins ranged from 1 in. in the Patawa Creek and Wildhorse Creek subbasins on the lowland plains to as much as 14 in. in the Umatilla River above Meacham Creek subbasin in the Blue Mountains (table 1). Permitted surfacewater withdrawals for irrigation were greater than 1 percent of the estimated base flow in the subbasins of McKay Creek (6 percent), Patawa Creek (42 percent), and Wildhorse Creek (124 percent).

Mean annual deep aquifer recharge in subbasins analyzed for this study ranged from 4 in. in the Patawa Creek and Wildhorse Creek subbasins on the lowland plains to as much as $8 \mathrm{in}$. in the Isqu'ulktpe Creek subbasin in the Blue Mountains (table 1; maximum values are shown in fig. $8 B$ ). The uncertainty in deep recharge due to permitted, but unmeasured surface water withdrawals was a small proportion of the deep recharge at sites in the Blue Mountains. Because more permitted, unmeasured withdrawals occur in the lowland plains, the uncertainty in deep recharge is greater than in the Blue Mountains. For example, McKay Creek had the most estimated maximum irrigation withdrawals in the Blue Mountains region, but these accounted for only 4 percent of the maximum deep recharge (total recharge minus base flow). In contrast, in Wildhorse Creek in the lowland plains region, estimated maximum irrigation withdrawals accounted for 16 percent of the maximum deep recharge (total recharge minus base flow).

Estimates of mean annual deep aquifer recharge for the entire study area and for the Blue Mountains and lowland plains regions were extrapolated from the base flow and permitted maximum surface-water withdrawals in the measured subbasins (table 1; maximum values are shown in fig. $8 D$ ) by scaling the measured values by the ratio of the measured to unmeasured area, as described in section, "Methods." Mean annual deep recharge across the entire study area was about 5 in. Deep aquifer recharge generally was largest in the Blue Mountains (6 in.), and smallest in the lowland plains (3-4 in.) where precipitation was lowest and potential surface-water withdrawals were largest. However, as a percentage of total recharge, deep recharge was largest in the lowland plains where an estimated 67-84 percent of the total recharge infiltrates to the deeper aquifers below the base level of the streams. Reasons for this are explained in section, "Discussion." 


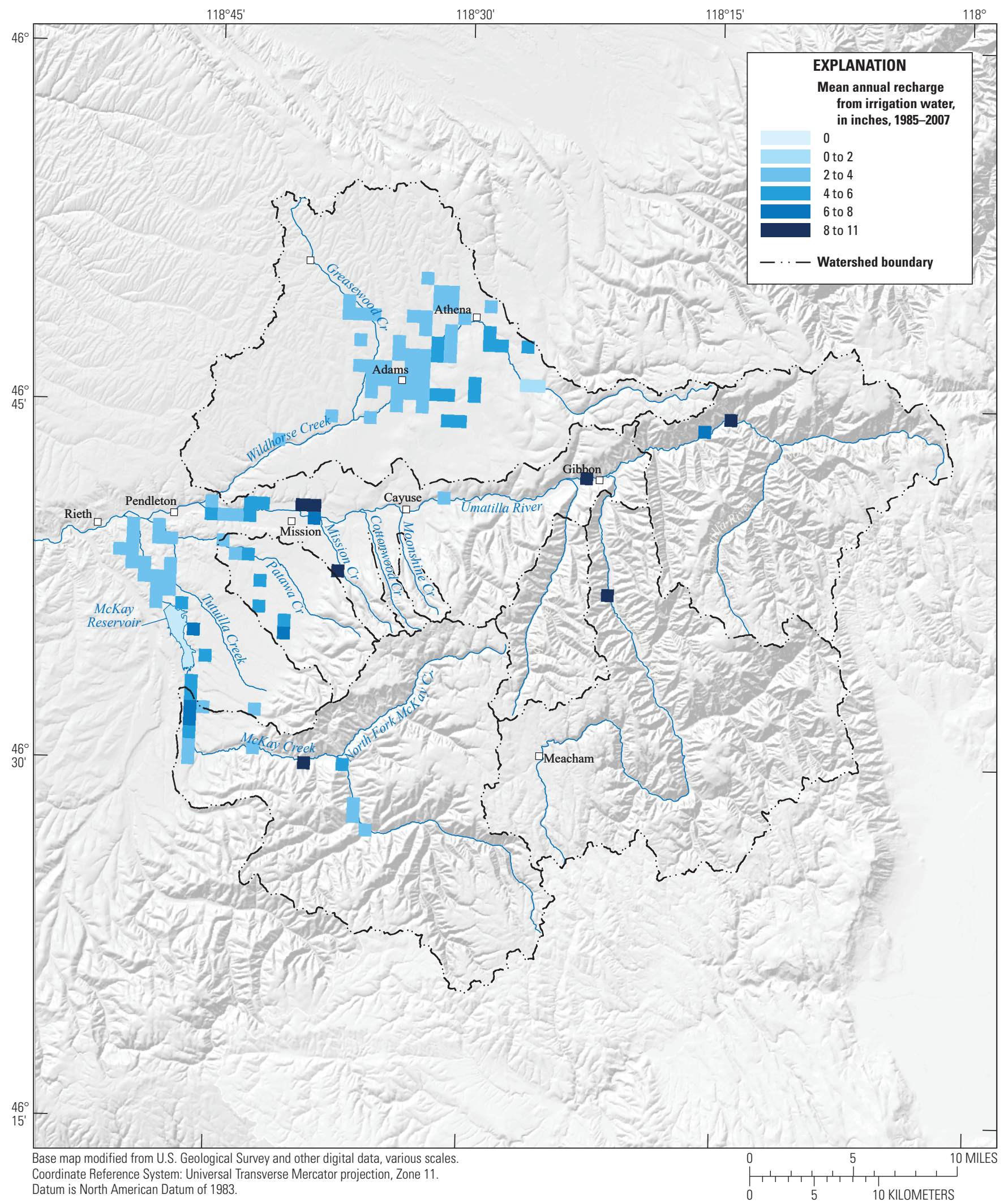

Figure 7. Mean annual total recharge from application of irrigation water, upper Umatilla River Basin, northeastern Oregon, 1985-2007. 


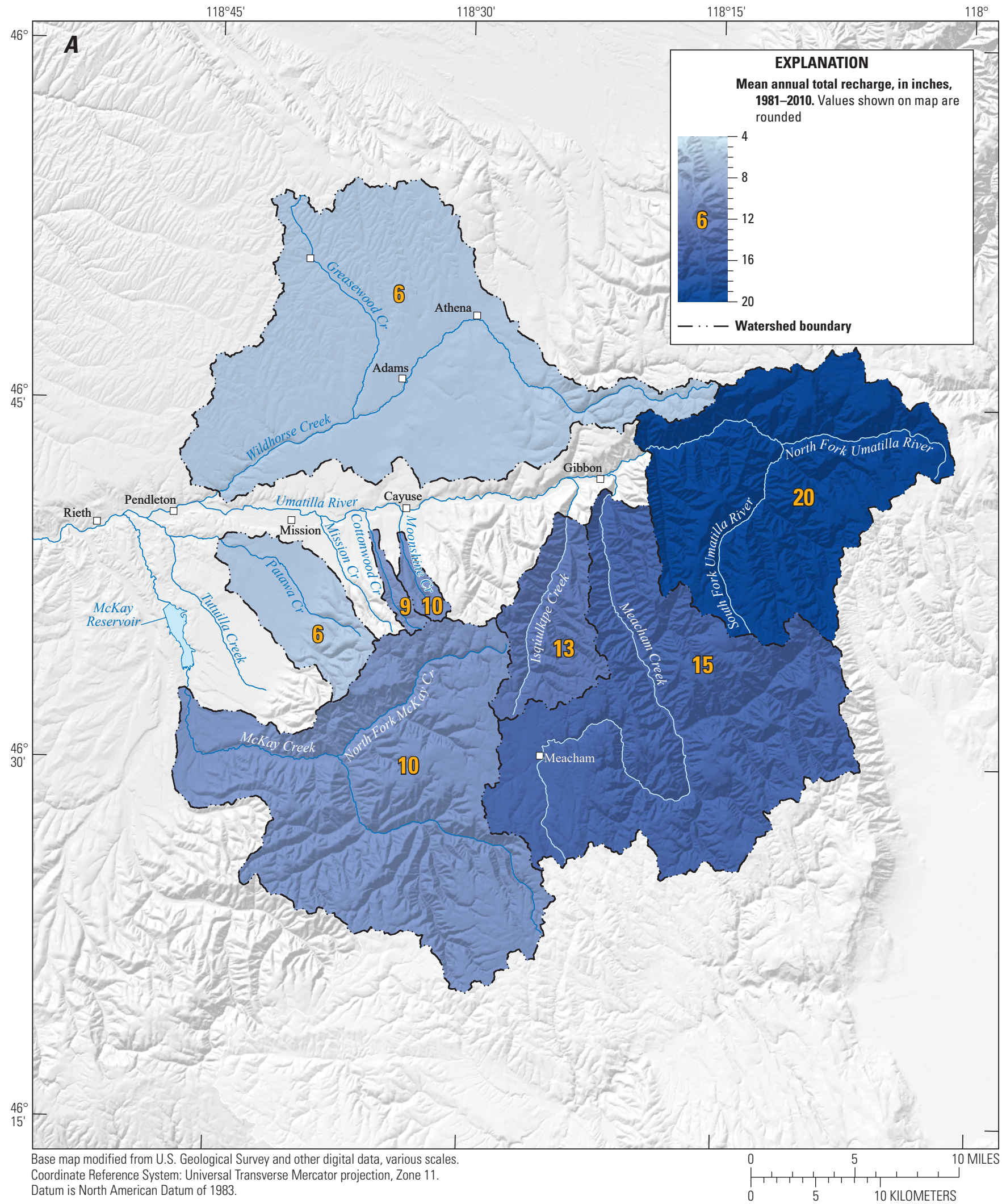

Figure 8. Mean annual total recharge and maximum deep aquifer recharge for selected regions, upper Umatilla River Basin, northeastern Oregon, 1981-2010. (A) Mean annual total recharge for selected subbasins. (B) Maximum mean annual deep aquifer recharge for selected subbasins. (C) Mean annual total recharge for the Blue Mountains and Lowland Plains regions. (D) Maximum mean annual deep aquifer recharge for the Blue Mountains and lowland plains regions. 


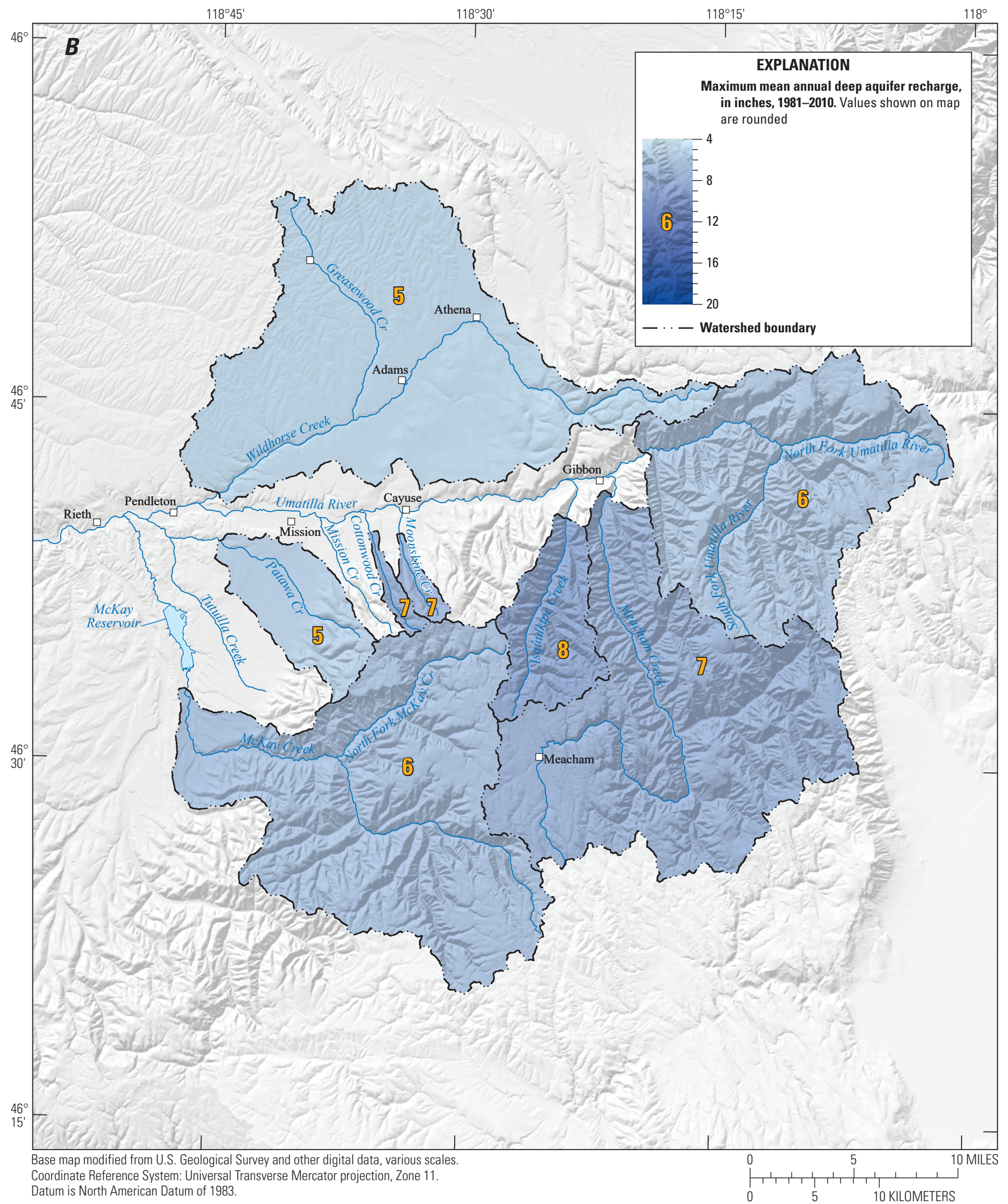

Figure 8.-Continued. 


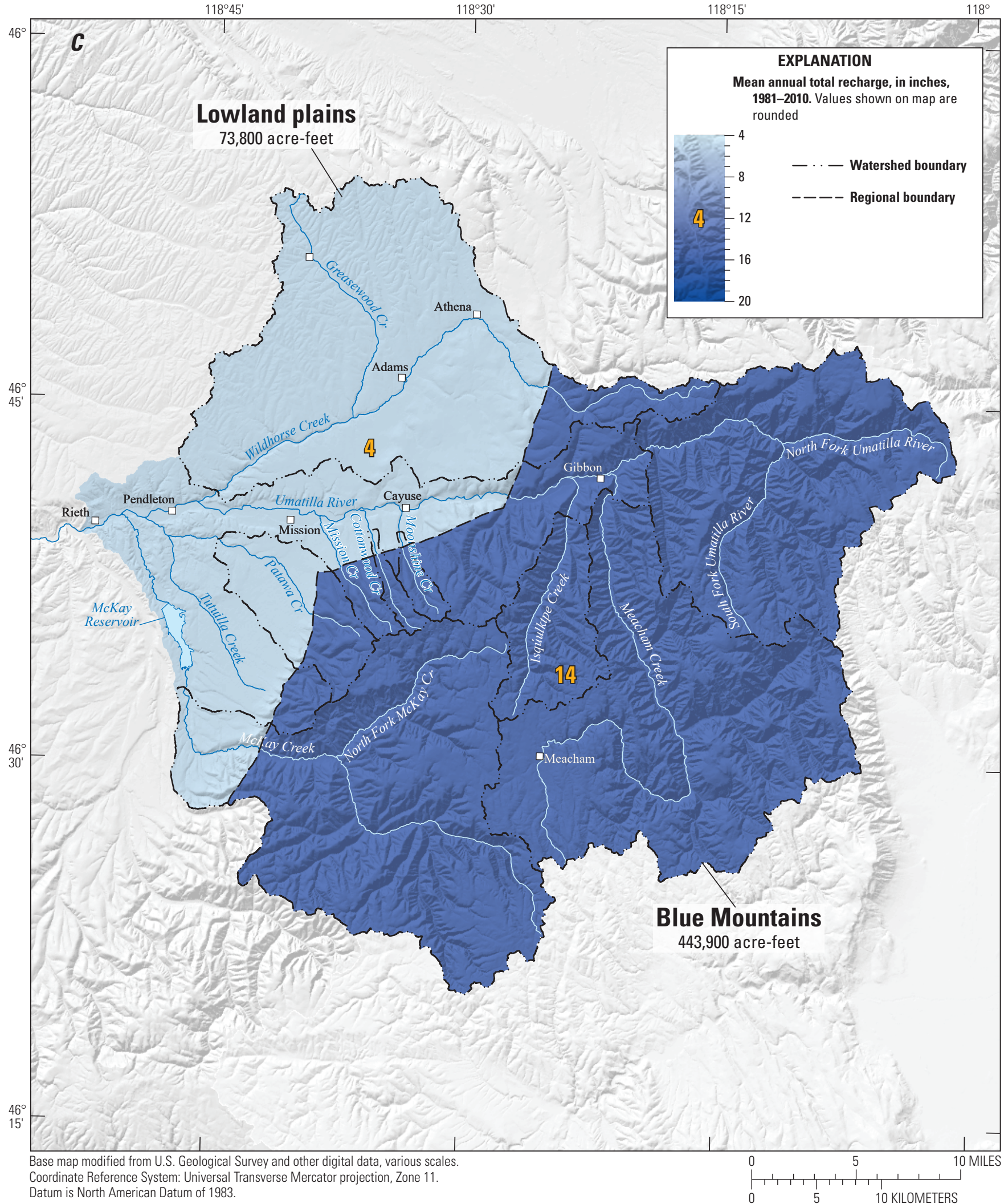

Figure 8.-Continued. 


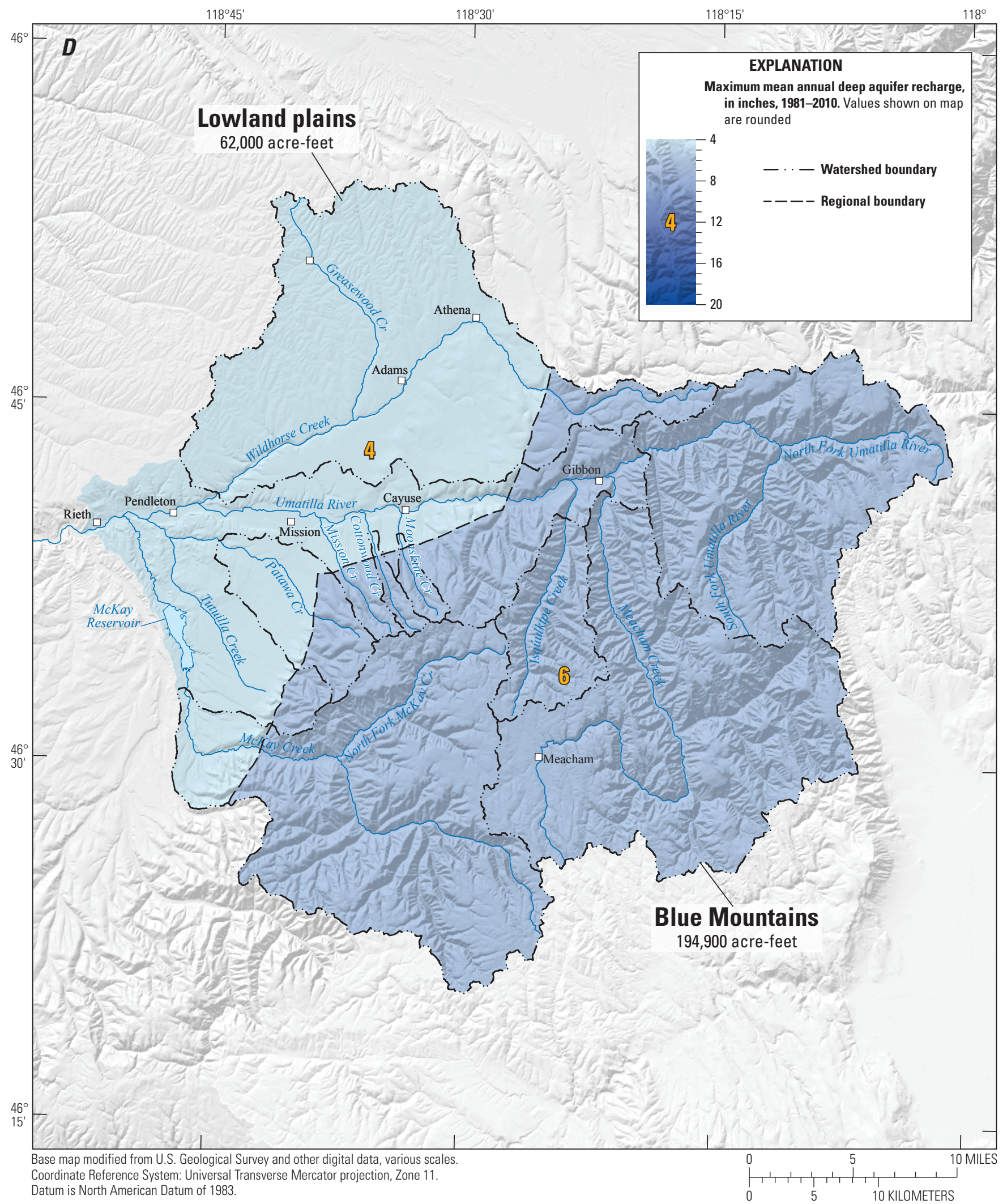

Figure 8.-Continued. 


\section{Discussion}

Most groundwater recharge (both total and deep aquifer) in the study area occurred in the Blue Mountains, which highlights the importance of the Blue Mountains as the principal source of groundwater for the study area and for aquifers farther downgradient. Mean annual total recharge in the Blue Mountains region was estimated at 14 in. ${ }^{1}$ or 443,900 acre-ft. This represents 86 percent of the total recharge in the study area $(517,700$ acre-ft) in an area that encompasses 65 percent of the study area. However, only 43-44 percent of the total recharge (192,200-194,900 acre-ft) remains in the system to recharge the deeper, regional aquifer system because the rest is discharged as base flow within the Blue Mountains region. Within the lowland plains region of the study area, an estimated 67-84 percent of the total recharge remains in the system to recharge the deep, regional aquifer system. Although total recharge in the lowland plains region represents only 14 percent of the total recharge across the study area, it contributes 20-24 percent of the water to the deep aquifer.

The difference in the percentage of deep groundwater recharge in the Blue Mountains and the lowland plains primarily is attributed to differences in the degree of stream incision. In the Blue Mountains region, stream channels are incised, on average, about $940 \mathrm{ft}$ below the surrounding land surface. In the lowland plains region, stream channels are incised, on average, about $160 \mathrm{ft}$ below the surrounding land surface. Stream incision was defined as the difference in elevation between the stream channel and the maximum elevation of the surrounding landscape within 0.6-mi of the channel. The dissection of the landscape in the Blue Mountains disrupts the lateral continuity of the CRBG aquifer units and allows groundwater to discharge to springs and streams rather than infiltrate more deeply. The horizontal movement of water is favored because of large anisotropy of hydraulic conductivity in the CRBG aquifers (Bauer and Hansen, 2000, Tolan and others, 2009; Kahle and others, 2011). In the lowland plains region, incision is much less pronounced and deeper CRBG units likely retain their lateral continuity, enabling groundwater to infiltrate more deeply than in the Blue Mountains. Because hydrogeologic properties of the CRBG units in the Blue Mountains and the lowland plains are similar, differences in the percentage of deep aquifer recharge are wholly attributed to the degree of dissection.

The distinction between total and deep recharge is important for the understanding and management of

\footnotetext{
${ }^{1}$ Recharge rates were useful for earlier comparisons among subbasins, but are less helpful in discussions of water availability. Therefore, further discussion will refer to recharge using volumetric flow rate units of acre-feet per year.
}

groundwater resources in the upper Umatilla River Basin. In the Blue Mountains region where most recharge occurs, 56 percent of the total recharge re-emerges as base flow and the remaining 44 percent recharges the regional groundwaterflow system. Population is sparse and agriculture is limited to narrow stream valleys in this rugged part of the study area; therefore, groundwater use is low. The deep recharge in the Blue Mountains region is the single largest source of groundwater recharge for the deep basalt aquifers underlying the lowland plains, which serve municipal and irrigation uses in that region.

\section{Study Limitations and Future Work}

Because many of the components used to calculate recharge are difficult to measure directly or quantify, these estimates contain some uncertainty; however, these uncertainties are not expected to change the overall conclusions of the report. The estimate of recharge due to precipitation shown here, developed using the regression method of Bauer and Vaccaro (1990), compares favorably with an independent estimate of recharge for a relatively large watershed in the study area developed using PRMS by Yazzie and Chang (2017). The use of a process-based model, such as PRMS, for the entire study area could improve recharge estimates by accounting for spatial heterogeneity of land surface characteristics such as soils and land use. Additional weather stations in the study area would improve long-term precipitation estimates, which are used in the regression method of Bauer and Vaccaro (1990) and PRMS. Surface-water withdrawals were estimated for this study from water-rights permits, but uncertainty in amount and timing of the withdrawals make it difficult to account for them in the stream hydrographs and resulting base-flow analyses. Recent work to improve hydrograph-separation methods, with the goal of improving estimates of base flow, has focused on non-graphical techniques such as chemical mass balance (Stewart and others, 2007; Miller and others, 2015), recursive digital filters (Nathan and McMahon, 1990; Eckhardt, 2005), and hybrid techniques that use the strengths of all methods (Raffensperger and others, 2017). Many of these techniques rely on data such as water chemistry unavailable for this study, but could provide improved estimates of groundwater discharge to streams. Additionally, seepage-run estimates could be made to update work done by Herrera and others (2017), and to include stream basins not included in their work that would be useful in the estimation of deep aquifer recharge in the study area. 


\section{Summary}

Groundwater is an important component of the water resources of the semi-arid upper Umatilla River Basin of northeastern Oregon. As such, understanding the capacity of the groundwater resource is vital. The purpose of this work is to better quantify the spatial distribution and variability of deep aquifer recharge in the study area, and to understand the reasons for a relatively low percentage of total recharge reaching the deeper parts of the groundwater-flow system.

The upper Umatilla River Basin study area encompasses the drainage of the Umatilla River from its headwaters in the Blue Mountains to just west of the confluence of the Umatilla River with Wildhorse and McKay Creeks. The study area is divided into two distinct physiographic areas - the highly dissected Blue Mountains to the east and gently undulating lowland plains to the west. The foothills and plains support the major communities and nearly all the agricultural development in the study area. Mean annual precipitation is greatest in the upper elevations of the Blue Mountains and generally decreases to the west with decreasing elevation. Mean annual precipitation averaged 34 inches (in.) in the Blue Mountains during 1981-2010, much of which fell as snow. Precipitation averaged $18 \mathrm{in.}$ across the lowland plains.

Underlying the study area are basalts of the Columbia River Basalt Group (CRBG). Folding and faulting uplifted the Blue Mountains relative to the lowland plains, and have resulted in deep incision by streams on the uplifted block. The CRBG is the principal aquifer in the study area and is composed of numerous flows stacked one upon the other. In general, the flows are laterally extensive except where cut by faulting, incised by streams, or pinched out by paleotopography. The vesicular and brecciated flow tops and bottoms of individual flows are the principal aquifers and water-bearing zones; the flow interiors typically are dense and have much lower permeability. In the Blue Mountains, streams are deeply incised through the CRBG strata, whereas on the lowland plains, stream incision is less pronounced. Where CRBG strata are deeply incised, the lateral continuity of the CRBG aquifer units is disrupted and infiltrating groundwater is more readily diverted laterally and discharged to streams and springs. Where incision is less pronounced, the shallow CRBG aquifer units might be disrupted but deeper aquifer units retain their lateral continuity and enable groundwater to infiltrate deeper and flow laterally farther downgradient before discharging.

Previous estimates of recharge in the study area ranged from 0.1 to 2 in. in the lowlands near Pendleton and from 10 to $40 \mathrm{in}$. in the Blue Mountains. One recent study of the upper Umatilla River Basin indicated that 80 percent of recharge entering the groundwater system discharged to streams in the study area through shallow groundwater-flow paths, leaving about 20 percent of recharge to infiltrate to deeper parts of the aquifer system. This deep recharge supplies water to the basalt aquifers in the lowland part of the study area (and farther downgradient), from which water most often is withdrawn for municipal and irrigation uses.

Recharge to the deep basalt aquifers is estimated as the difference between total recharge and base flow. Total recharge is the portion of precipitation and applied irrigation water that infiltrates past the root zone to become groundwater recharge. Of this total recharge, a proportion discharges to springs and streams in the study area, and the remaining water infiltrates below the base level of streams and recharges the deep basalt aquifers and contributes to the regional groundwater flow system. The portion of total recharge that recharges the regional flow system is referred to as deep aquifer recharge.

Recharge from infiltration of precipitation is estimated using a regression method developed for the Columbia Plateau. Input for this method is mean annual precipitation. For this analysis, 30 arc-second gridded mean annual precipitation for 1981-2010 was used. Recharge from infiltrating irrigation water was obtained from a water balance model developed for the Columbia Plateau. Total recharge is the sum of recharge from precipitation and recharge from irrigation.

Base flow, the component of streamflow that represents groundwater discharge as opposed to runoff from the land surface, was estimated using the Base Flow Index Modified (BFI-Modified) method, an empirical hydrograph separation technique. Base flow was estimated in eight subbasins with streamgages within the study area. Five of the eight subbasins in which base flow was estimated had permitted water rights for irrigation that specified surface water as the primary source of water. Maximum surface-water withdrawal for irrigation was estimated for all subbasins in which water rights for irrigation occur.

The base-flow estimate from BFI-Modified is assumed to be the minimum amount of base flow. The sum of the BFI-Modified base-flow estimate and the maximum permitted surface-water withdrawal estimate for each subbasin is assumed to be the maximum amount of base flow at the streamgage.

Using minimum and maximum base-flow estimates, a minimum and maximum value of deep aquifer recharge was calculated for each subbasin in which base flow was estimated. Minimum deep aquifer recharge is calculated as the difference between total recharge within the subbasin and maximum base flow (defined as the sum of the BFI-Modified base-flow estimate and the maximum permitted surfacewater withdrawal in each subbasin). Maximum deep aquifer recharge is defined as the difference between total recharge within the subbasin and BFI-Modified base flow. 
Estimates of deep aquifer recharge in the Blue Mountains and lowland plains were generated in the manner described in the previous paragraph by scaling up values of base flow and estimated surface-water diversions in subbasins within each respective region. An estimate of deep aquifer recharge for the entire study area was generated by adding the scaled regional values of base flow and surface-water diversions to obtain study area-wide values. These were used to calculate maximum and minimum deep aquifer recharge for the study area.

Mean annual total recharge for 1981-2010 in the subbasins analyzed as part of this work ranged from 6 in. in the Patawa and Wildhorse Creek subbasins in the lowland plains to as much as $20 \mathrm{in}$. in the Umatilla River above Meacham Creek subbasin. Mean annual total recharge totaled 4 in. in the lowland plains region and 14 in. in the Blue Mountains. Mean annual total recharge for the entire study area was 11 in.

Mean annual base flow ranged from 1 in. in the Patawa and Wildhorse Creek subbasins in the lowland plains to as much as 14 in. in the Umatilla River above Meacham Creek subbasin in the Blue Mountains.

Mean annual deep aquifer recharge ranged from 4 in. in the Patawa and Wildhorse Creek subbasins in the lowland plains to as much as $8 \mathrm{in}$. in the Isqu'ulktpe Creek subbasin in the Blue Mountains. Deep aquifer recharge was 3-4 in. in the lowland plains region and 6 in. in the Blue Mountains. Over the entire study area, mean annual deep aquifer recharge was 5 in.

Most groundwater recharge (both total and deep aquifer) in the study area occurred in the Blue Mountains, which highlights the importance of the Blue Mountains as the principal source of groundwater for the study area and for aquifers farther downgradient. Total recharge in the Blue Mountains region represents 86 percent of the mean annual total recharge in the study area in an area that encompasses 65 percent of the study area. However, only 43-44 percent of the mean annual total recharge remains in the system to recharge the deeper, regional aquifer system because the rest is discharged as base flow within the Blue Mountains region. Within the lowland plains region of the study area, an estimated 67-84 percent of the mean annual total recharge remains in the system to recharge the deep, regional aquifer system. Although total recharge in the study area represents only 14 percent of the total recharge across the study area, it contributes 20-24 percent of the water to the deep aquifer.

The difference in the percentage of deep groundwater recharge in the Blue Mountains and the lowland plains primarily is attributed to differences in the degree of stream incision. Stream channels are more incised in the Blue Mountains region than they are in the lowland plains. The dissection of the landscape in the Blue Mountains disrupts the lateral continuity of the CRBG aquifer units and allows groundwater to discharge to springs and streams rather than infiltrate more deeply. In the lowland plains region, incision is much less pronounced and deeper CRBG units likely retain their lateral continuity, enabling groundwater to infiltrate more deeply than in the Blue Mountains.

Continued study of the upper Umatilla River Basin will provide further insight into the interplay between groundwater and hydrogeology of the study area. The use of a processbased model, such as the Precipitation-Runoff Modeling System (PRMS) for the entire study area could improve recharge estimates by accounting for spatial heterogeneity of land surface characteristics such as soils and land use. Improvements to base-flow estimates using non-graphical techniques would help constrain the volume of water exiting the groundwater system before becoming deep aquifer recharge. Additionally, seepage run estimates could be done to update previous work and to improve understanding of base flow to streams in the study area.

\section{References Cited}

Barlow, P.M., Cunningham, W.L., Zhai, T., and Gray, M., 2015, U.S. Geological Survey groundwater toolbox, a graphical and mapping interface for analysis of hydrologic data (version 1.0) - User guide for estimation of base flow, runoff, and groundwater recharge from streamflow data: U.S. Geological Survey Techniques and Methods, book 3, chap. B10, 27 p., accessed July 2017, at http://dx.doi. org $/ 10.3133 / \mathrm{tm} 3 \mathrm{~B} 10$.

Bauer, H.H., and Hansen, A.J., 2000, Hydrology of the Columbia Plateau regional aquifer system, Washington, Oregon, and Idaho: U.S. Geological Survey WaterResources Investigations Report 96-4106, 61 p., accessed January 2018, at https://pubs.er.usgs.gov/publication/ wri964106.

Bauer, H.H., and Vaccaro, J.J., 1987, Documentation of a deep percolation model for estimating ground-water recharge: U.S. Geological Survey Open-File Report 86-536, 180 p., accessed September 2016, at https://pubs.er.usgs.gov/ publication/ofr86536.

Bauer, H.H., and Vaccaro, J.J., 1990, Estimates of groundwater recharge to the Columbia Plateau regional aquifer system, Washington, Oregon, and Idaho, for predevelopment and current land-use conditions: U.S. Geological Survey Water-Resources Investigations Report 88-4108, 37 p., accessed September 2016, at https://pubs. er.usgs.gov/publication/wri884108. 
Burns, E.R., Morgan, D.S., Lee, K.K., Haynes, J.V., and Conlon, T.D., 2012, Evaluation of long-term water-level declines in basalt aquifers near Mosier, Oregon: U.S. Geological Survey Scientific Investigations Report 20125002, 134 p., accessed January 2018, at https://pubs.er.usgs. gov/publication/sir20125002.

Davies-Smith, A., Bolke, E.L., and Collins, C.A., 1988, Geohydrology and digital simulations of the ground-water flow system in the Umatilla Plateau and Horse Heaven Hills area, Oregon, and Washington: U.S. Geological Survey Water-Resources Investigations Report 87-4268, 77 p., accessed January 2018, at https://pubs.er.usgs.gov/ publication/wri874268.

Eckhardt, K., 2005, How to construct recursive digital filters for baseflow separation: Hydrological Processes, v. 19, no. 2, p. 507-515, accessed February 2018, at https://doi. org/10.1002/hyp.5675.

Ely, D.M., Burns, E.R., Morgan, D.S., and Vaccaro, J.J., 2014, Numerical simulation of groundwater flow in the Columbia Plateau regional aquifer system, Idaho, Oregon, and Washington: U.S. Geological Survey Scientific Investigations Report 2014-5127, 90 p., accessed October 2016, at https://pubs.er.usgs.gov/publication/sir20145127.

Ferns, M.L., McConnell, V.S., and Madin, I.P., 2006, Geology of the Umatilla River Basin, Morrow, Umatilla, and Union Counties, Oregon: Oregon Department of Geology and Mineral Industries, 64 p., 4 apps., and 12 pls.

Gonthier, J.B., and Bolke, E.L., 1993, Summary appraisal of water resources of the Umatilla Indian Reservation: U.S. Geological Survey Water-Resources Investigations Report 91-4087, 54 p., accessed October 2016, at https://pubs. er.usgs.gov/publication/wri914087.

Hansen, A.J., Vaccaro, J.J., and Bauer, H.H., 1994, Groundwater flow simulation of the Columbia Plateau regional aquifer system, Washington, Oregon, and Idaho: U.S. Geological Survey Water-Resources Investigations Report 91-4187, 81 p., accessed January 2018, at https://pubs. er.usgs.gov/publication/wri914187.

Herrera, N.B., Ely, K., Mehta, S., Stonewall, A.J., Risley, J.C., Hinkle, S.R., and Conlon, T.D., 2017, Hydrogeologic framework and selected components of the groundwater budget for the upper Umatilla River Basin, Oregon: U.S. Geological Survey Scientific Investigations Report 20175020, 57 p., accessed September 2016, at https://doi. org/10.3133/sir20175020.
Hogenson, G.M., 1964, Geology and ground water of the Umatilla River Basin, Oregon: U.S. Geological Survey Water-Supply Paper 1620, 162 p., accessed October 2016, at https://pubs.er.usgs.gov/publication/wsp1620.

Kahle, S.C., Morgan, D.S., Welch, W.B., Ely, D.M., Hinkle, S.R., Vaccaro, J.J., and Orzol, L.L., 2011, Hydrogeologic framework and hydrologic budget components of the Columbia Plateau regional aquifer system, Washington, Oregon, and Idaho: U.S. Geological Survey Scientific Investigations Report 2011-5124, 66 p., accessed October 2016, at https://pubs.er.usgs.gov/ publication/sir20115124.

Leavesley, G.H., Lichty, R.W., Troutman, B.M., and Saindon, L.G., 1983, Precipitation-runoff modeling system-User's manual: U.S. Geological Survey WaterResources Investigations Report 83-4238, 207 p., accessed July 2017, at https://pubs.er.usgs.gov/publication/ wri834238.

Markstrom, S.L., Regan, R.S., Hay, L.E., Viger, R.J., Webb, R.M.T., Payn, R.A., and LaFontaine, J.H., 2015, PRMS-IV, the precipitation-runoff modeling system, version 4: U.S. Geological Survey Techniques and Methods, book 6, chap. B7, 158 p., accessed July 2017, at https:// pubs.usgs.gov/tm/6b7/.

Miller, M.P., Johnson, H.M., Susong, D.D., and Wolock, D.M., 2015, A new approach for continuous estimation of baseflow using discrete water quality data-Method description and comparison with baseflow estimates from two existing approaches: Journal of Hydrology (Amsterdam), v. 522, p. 203-210, accessed February 2018, at https://doi.org/10.1016/j.jhydrol.2014.12.039.

Nathan, R.J., and McMahon, T.A., 1990, Evaluation of automated techniques for base flow and recession analyses: Water Resources Research, v. 26, no. 7, p. 1465-1473, accessed February 2018, at https://doi.org/10.1029/ WR026i007p01465.

Pischel, E.M., 2018, Selected data from deep aquifer recharge in the Columbia River Basalt Group, Upper Umatilla River Basin, northeastern Oregon: U.S. Geological Survey data release, https://doi.org/10.5066/P9E548IN.

PRISM Climate Group, 2016, PRISM climate data: Corvallis, Oregon State University, PRISM Climate Group database, accessed September 2016, at http://www.prism.oregonstate. edu/. 
Raffensperger, J.P., Baker, A.C., Blomquist, J.D., and Hopple, J.A., 2017, Optimal hydrograph separation using a recursive digital filter constrained by chemical mass balance, with application to selected Chesapeake Bay watersheds: U.S. Geological Survey Scientific Investigations Report 2017-5034, 51 p., accessed February 2018, at https://doi.org/10.3133/sir20175034.

Rutledge, A.T., 1998, Computer programs for describing the recession of ground-water discharge and for estimating mean ground-water recharge and discharge from streamflow records - Update: U.S. Geological Survey Water-Resources Investigations Report 98-4148, 43 p., accessed February 2018, at https://pubs.usgs.gov/wri/wri984148/.

Sloto, R.A., and Crouse, M.Y., 1996, HYSEP-A computer program for streamflow hydrograph separation and analysis: U.S. Geological Survey Water-Resources Investigations Report 96-4040, 46 p., accessed February 2018, at https:// pubs.er.usgs.gov/publication/wri964040.

Stewart, M., Cimino, J., and Ross, M., 2007, Calibration of base flow separation methods with streamflow conductivity: Ground Water, v. 45, no. 1, p. 17-27, accessed February 2018, at https://doi.org/10.1111/j.1745-6584.2006.00263.x.
Tolan, T.L., Lindsey, K.A., and Porcello, J.J., 2009, Summary of Columbia River Basalt Group geology and its influence on the hydrogeology of the Columbia River basalt aquifer system - Columbia Basin ground water management area of Adams, Franklin, Grant, and Lincoln Counties: Prepared for the Columbia Basin groundwater management area of Adams, Franklin, Grant, and Lincoln Counties, 32 p.

Western Regional Climate Center, 2018, Meacham, Oregon, period of record monthly climate summary: Western Regional Climate Center web page, accessed January 24, 2018, at https://wrcc.dri.edu/cgi-bin/cliMAIN.pl?or5396.

Wahl, K.L., and Wahl, T.L., 1995, Determining the flow of Comal Springs at New Braunfels, Texas, in Proceedings of Texas Water '95 Conference, August 16-17, 1995, San Antonio, Texas: American Society of Civil Engineers, p. 77-86.

Yazzie, K., and Chang, H., 2017, Watershed response to climate change and fire-burns in the upper Umatilla River Basin, USA: Climate, v. 5, no. 1, 22 p., accessed February 2017, at https://doi.org/10.3390/cli5010007. 

Publishing support provided by the U.S. Geological Survey Science Publishing Network, Tacoma Publishing Service Center

For more information concerning the research in this report, contact the Director, Oregon Water Science Center U.S. Geological Survey

2130 SW 5th Avenue

Portland, Oregon 97201

https://www.usgs.gov/centers/or-water 


\section{$\frac{\mathbb{3}}{3}$}

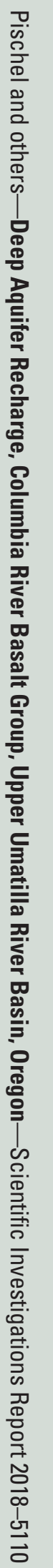

